\title{
Mononuclear non-heme iron(III) complexes of linear and tripodal tridentate ligands as functional models for catechol dioxygenases: Effect of $N$-alkyl substitution on regioselectivity and reaction rate
}

\author{
MALLAYAN PALANIANDAVAR* and KUSALENDIRAN VISVAGANESAN \\ Centre for Bioinorganic Chemistry, School of Chemistry, Bharathidasan University, \\ Tiruchirappallli 620 024, India \\ e-mail: palanim51@yahoo.com; palaniandavarm@gmail.com
}

\begin{abstract}
Catechol dioxygenases are responsible for the last step in the biodegradation of aromatic molecules in the environment. The iron(II) active site in the extradiol-cleaving enzymes cleaves the $\mathrm{C}-\mathrm{C}$ bond adjacent to the hydroxyl group, while the iron(III) active site in the intradiol-cleaving enzymes cleaves the $\mathrm{C}-\mathrm{C}$ bond in between two hydroxyl groups. A series of mononuclear iron(III) complexes of the type $\left[\mathrm{Fe}(\mathrm{L}) \mathrm{Cl}_{3}\right]$, where $\mathrm{L}$ is the linear $N$-alkyl substituted bis(pyrid-2-ylmethyl)amine, $N$-alkyl substituted $N$ (pyrid-2-ylmethyl)ethylenediamine, linear tridentate $3 \mathrm{~N}$ ligands containing imidazolyl moieties and tripodal ligands containing pyrazolyl moieties have been isolated and studied as structural and functional models for catechol dioxygenase enzymes. All the complexes catalyse the cleavage of catechols using molecular oxygen to afford both intra- and extradiol cleavage products. The rate of oxygenation depends on the solvent and the Lewis acidity of iron(III) center as modified by the sterically demanding $N$-alkyl groups. Also, our studies reveal that stereo-electronic factors like the Lewis acidity of the iron(III) center and the steric demand of ligands, as regulated by the $N$-alkyl substituents, determine the regioselectivity and the rate of dioxygenation. In sharp contrast to all these complexes, the pyrazole-containing tripodal ligand complexes yield mainly the oxidized product benzoquinone.
\end{abstract}

Keywords. Catechol dioxygenases; functional models; mononuclear iron(III) complexes; Lewis acidity; regioselectivity.

\section{Introduction}

Aromatic compounds pose a major hazard to the environment, being mutagenic, carcinogenic, and recalcitrant. ${ }^{1}$ The toxicity of aromatic compounds is derived from their biological activation, which generates intermediates (hydroxy aromatics) like epoxide or catechol derivatives. These intermediates are highly reactive and yield reactive oxygen species (ROS), form covalent adduct with macromolecules like nucleic acids and cause protein inactivation. A number of soil bacteria, especially Pseudomonas, have the metabolic capability to degrade aromatic compounds and utilize these compounds as the sole carbon source for growth. ${ }^{2-4}$ An important step in these catabolic pathways is insertion of both the $\mathrm{O}$-atom of molecular oxygen into 1,2-dihydroxyaromatic compounds, or their substituted

*For correspondence compounds, to give ring opened products and the enzymes involved in these catabolic reactions are called catechol dioxygenases. These enzymes can be divided into two subclasses based on their position of ring opening of catechols, both families utilizing catechol and molecular oxygen as substrates (scheme 1). ${ }^{5-7}$ The intradiol dioxygenases ${ }^{8-13}$ cleave the carboncarbon double bond between the phenolic hydroxyl groups to yield muconic acid as product, and require $\mathrm{Fe}^{3+}$ as a cofactor. The extradiol dioxygenases, ${ }^{14-19}$ cleave the carbon-carbon bond adjacent to the phenolic hydroxyl groups to yield 2-hydroxymuconaldehyde as product, and require $\mathrm{Fe}^{2+}$ as a cofactor. The molecular structure of three extradiol-cleaving catechol dioxygenases namely 2,3-dihydroxybiphenyl-1,2dioxygenase $(\mathrm{BphC})$, catechol-2,3-dioxygenase (2,3CTD) and protocatechuate-4,5-dioxygenase (4,5-PCD) have been determined and found that in all these enzymes the mononuclear iron(II) center is coordinated by two histidine ligands, one glutamic acid ligand and two water molecules in a square pyramidal shape. In contrast, the mononuclear iron(III) center 

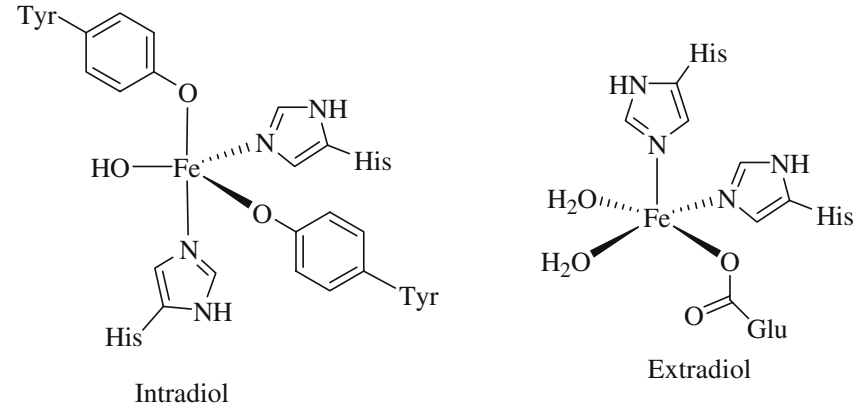

Scheme 1. Active site structures of intradiol and extradiolcleaving dioxygenase enzymes.

of the intradiol-cleaving enzymes protocatechuate-3,4dioxygenase (3,4-PCD) and catechol-1,2-dioxygenase (1,2-CTD) is ligated by two histidine ligands and two tyrosine ligands. Each family of enzyme was quite specific for the production of their respective reaction product with a range of substrates (scheme 2 ). In the absence of catalyst, the reaction of $\mathrm{O}_{2}(\mathrm{~S}=1)$ with organic substrates $(\mathrm{S}=0)$ is thermodynamically favourable but kinetically slow because of the spinforbidden nature of the reaction. Hence, either $\mathrm{O}_{2}$ or the substrate needs to be activated to overcome the kinetic barrier resulting from their spin. Such activation has been achieved by non-heme iron enzymes and their small molecule analogues. The reasons for different metal ion requirement of the two families of enzyme, however, remained a mystery in the enzymatic pathway. ${ }^{20,21}$ The recent X-ray crystal structure of homoprotocatechuate 2,3-dioxygenase enzyme shows that three different intermediates reside in different subunits of a single homotetrameric enzyme molecule. ${ }^{22}$ Two aspects of this structure are particularly important, one is $\mathrm{O}_{2}$ molecule is bound side-on rather than more commonly encountered end-on. The other is the plane of the 4-NC (4-nitrocatechol) ring is puckered rather than planar. But it is interesting that no deviation from a planar aromatic ring is observed for the anaerobic complex of 2,3-HPCD with substrate.

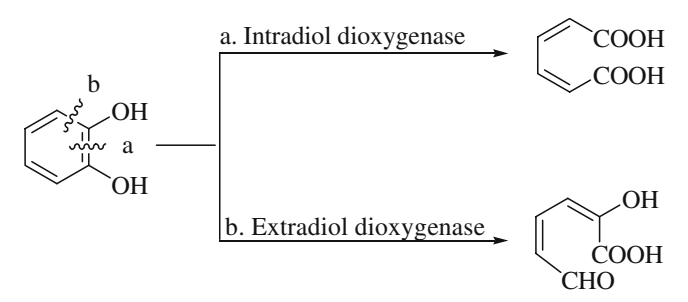

Scheme 2. Mode of cleavage of intradiol and extradiol dioxygenases.
Even though intradiol dioxygenases and their models ${ }^{23-33}$ have been more extensively studied and thus more understood, extradiol dioxygenase enzymes have not been studied in detail in spite of the latter constituting the more common iron enzymes for the biodegradation of aromatic molecules in the soil. The difficulty in studying extradiol dioxygenases could be attributed to lack of spectroscopic probes available for iron(II) and oxygen activation mechanism has been proposed ${ }^{34}$ for the extradiol cleavage. Solomon et al. have very recently found that the resting extradiol-cleaving enzymes fail to react with $\mathrm{O}_{2}$ but become reactive upon substrate binding. ${ }^{35}$ Recent growing interest has been shifted towards the extradiol-cleaving catechol dioxygenase and their model complexes and several small molecule analogues ${ }^{36-44}$ have been isolated and studied to get insight into the reaction mechanism of catechol cleavage. Earlier Funabiki et al. ${ }^{37}$ reported the first model by using $\mathrm{FeCl}_{2} / \mathrm{FeCl}_{3}$ with pyridine/bipyridine mixture. Later Die et al. $^{38}$ found that $[\mathrm{Fe}(\mathrm{TACN})(\mathrm{DBC}) \mathrm{Cl}]$ (TACN $=1,4,7$-triazacyclononane), upon exposure to molecular oxygen, yielded $35 \%$ of the extradiol product substituted 2-pyrones. Bugg et al. have found ${ }^{39}$ that iron(II) complex of TACN shows higher rates and higher reactivity in the extradiol cleavage and suggesting that iron(II) has an inherently higher chemical reactivity for extradiol cleavage than iron(III). It is worthy to note that iron(III)-catecholate adducts of cyclic tridentate (TACN and $\mathrm{Me}_{3}$ TACN) ligands would yield extradiol cleavage products quantitatively while some of the model complexes with facial tridentate ligands showed the formation of intradiol cleavage products even up to $50 \%$. Que etal. and Bugg et al. have studied the reactivity of $[\mathrm{Fe}(\mathrm{TACN})(\mathrm{DBC}) \mathrm{Cl}]$ with molecular oxygen and suggested that facial coordination of tridentate ligand and both mono- and dianionic catecholate binding lead to extradiol cleavage and that the iron-catecholate adduct must contain a vacant coordination site for oxygen binding. ${ }^{39-41}$ Que et al. ${ }^{41}$ and Palaniandavar et al. ${ }^{45}$ have recently reported that tridentate ligands with meridional coordination yields quinone and intradiol cleavage products as the major products and confirmed that facial coordination of tridentate ligands is essential to elicit extradiol cleavage (scheme 3). On substituting the $\mathrm{N}-\mathrm{H}$ hydrogen of TACN in $[\mathrm{Fe}(\mathrm{TACN})(\mathrm{DBC}) \mathrm{Cl}]$ by methyl groups as in $\left[\mathrm{Fe}\left(\mathrm{Me}_{3}-\right.\right.$ TACN)(DBC)Cl] nearly quantitative yield $(97 \%)$ of extradiol cleavage product is observed ${ }^{41}$ even without addition of pyridine. Very recently Gebbink et al. have isolated the iron(II)- and iron(III)-catecholate complexes of a new family of substituted 3,3-bis(1alkylimidazol-2-yl)propionate ligands and the iron(III) 

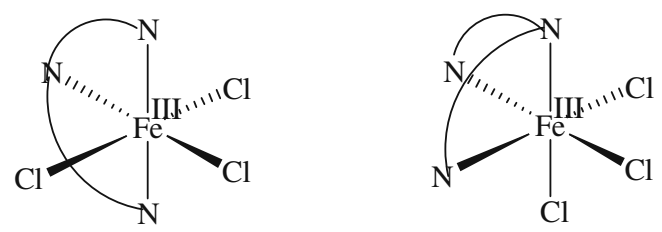

Scheme 3. Facial and meridional coordination of tridentate ligands to iron(III) center.

complexes elicit both the extra- and intradiol cleavage products in comparable amounts. ${ }^{46}$ Limberg et al. have found that iron(III) complexes of novel tripodal ligand containing three different heterocyclic donor functions yield both extra- and intradiol cleavage products (E:I, $2: 1$ ) in presence of sodium salt of tetraphenylborate. ${ }^{47}$ All these studies reveal that the steric and electronic properties of ligands coordinated to iron(III) lead to a dramatic difference in the cleavage preferences between the structurally similar catalysts.

In the present article, we summarize our results $^{27,45,48-50}$ on synthetic analogues for extradiolcleaving catechol dioxygenases. We have isolated many series of mononuclear iron(III) complexes of simple linear and tripodal tridentate ligands consisting of systematic variation on the Lewis basicity and steric hindrance. The systematic variation in the ligands, especially alkyl substitution on the amine (central and terminal $\mathrm{N}$-atom), would provide valuable information on the factors dictating regioselectivity of catechol cleavage. The X-ray crystal structures of the complexes and iron(III)-catecholate adducts provide valuable insight into the reaction mechanism of the cleavage. We have used 3,5-di-tert-butylcatechol $\left(\mathrm{H}_{2} \mathrm{DBC}\right)$ as the model substrate (scheme 4) and the advantages are the relatively high stability of the main cleavage product and the fast reaction of the catecholate complexes with dioxygen.

\section{Iron(III) complexes of meridionally coordinating tridentate ligands}

The iron(III) complexes $\left[\mathrm{Fe}(\mathrm{L} 1)\left(\mathrm{H}_{2} \mathrm{O}\right)_{2} \mathrm{Cl}\right] \mathbf{1}$, $\left[\mathrm{Fe}(\mathrm{L} 2) \mathrm{Cl}_{3}\right] \quad \mathbf{2}, \quad\left[\mathrm{Fe}(\mathrm{L} 3) \mathrm{Cl}_{3}\right] \quad \mathbf{3}$ and $\left[\mathrm{Fe}(\mathrm{L} 4) \mathrm{Cl}_{3}\right]$ 4, where $\mathrm{H}_{2} \mathrm{~L}$ is pyridine-2,6-dicarboxylic acid $\left(\mathrm{H}_{2} \mathrm{PDA}\right), \mathrm{L} 2$ is $2,2^{\prime}: 6,2^{\prime \prime}$-terpyridine (TPY), L3 is 2,6-bis(benzimidazolyl)pyridine (BBP) and L4 is bis (benzimidazol-2-ylmethyl)amine (BBA), have been used to mimic the function of intradiol-cleaving catechol dioxygenase enzymes (scheme 5). The tridentate ligands $\mathrm{PDA}^{2-}$, TPY and $\mathrm{BBP}$ are meridionally coordinated to iron(III) center as revealed in the $\mathrm{X}$-ray crystal structures of $\left[\mathrm{Fe}(\mathrm{PDA})\left(\mathrm{H}_{2} \mathrm{O}\right)_{2} \mathrm{Cl}\right]$ 1, $[\mathrm{Fe}(\mathrm{TPY})-$ $(\mathrm{DBC}) \mathrm{Cl}]$ 2a and $\left[\mathrm{Fe}\left(\mathrm{MBBP}^{\mathrm{C}} \mathrm{Cl}_{3}\right]\right.$ 3a $(\mathrm{MBBP}=$ 2,6-bis( $N$-methylbenzimidazol-2-yl)pyridine). ${ }^{51,52}$ In contrast, on replacing the pyridine backbone in L2 as in L4 which coordinates to iron(III) center in facial fashion due to the $\mathrm{sp}^{3}$ hybridization of amine $\mathrm{N}$-atom. ${ }^{27}$ Upon adding catecholate dianions to $\mathbf{1 - 4}$ in DMF two absorption features appear in the visible region (435-620 and $610-800 \mathrm{~nm}$ ), ${ }^{27,45}$ which are assigned to the catecholate-to-iron(III) charge-transfer transitions involving two different catecholate orbitals. ${ }^{25-27,53-55}$ The energies of both the bands are shifted to higher region as the substituents on the catecholate ring are varied from electron-donating to electron-withdrawing (figure 1). Electron-donating substituents would be expected to raise the energy of the catecholate frontier orbitals and thus minimize the ligand-to-metal energy gap. The position of low- rather than high-energy LMCT band exhibits a remarkable dependence on the nature of the tridentate ligand ${ }^{30,42,56,57}$ and the magnitude of energy of this band reflects the Lewis acidity of the iron(III) center as modified by the $3 \mathrm{~N}$ ligands. The low-energy LMCT band of iron(III)-DBC ${ }^{2-}$ adducts follow the trend $\mathbf{4}<\mathbf{2}<\mathbf{3}<\mathbf{1}$ (table 1), on replacing the py/bzim moiety in $\mathbf{2 / 3}$ by carboxylate groups to obtain 1, both the bands are slightly shifted to higher energies illustrating the decrease in Lewis acidity of the iron(III) center on coordination to the more basic carboxylate groups. Similarly, on replacing the pyridine pendant in $\mathbf{1}$ by benzimidazole as in $\mathbf{2}$, both the catecholate-to-iron(III) LMCT bands are shifted to higher energies illustrating the decrease in Lewis acidity of iron(III) center as expected. In contrast, on replacing the pyridine backbone in 3 as in $\mathbf{4}$, the LMCT band is shifted to lower energy due to the weak binding of amine $\mathrm{N}$-atom, which may increase the Lewis acidity and hence the reactivity. ${ }^{27}$ Thus the spectral studies reveal the importance of electronic factors of the tridentate ligands in tuning the Lewis acidity of the iron(III) center and hence the reactivity (cf. below). The similarity between the electronic spectra of the catecholate adducts of the present complexes and the catechol-bound enzymes suggests that the catecholato dianion is chelated to iron(III) center in the enzymes. ${ }^{22}$ The electrochemical properties of $\mathbf{1}-\mathbf{3}$ have been studied in DMF and $\mathrm{Fe}^{\mathrm{III}} / \mathrm{Fe}^{\mathrm{II}}$ redox potentials (table 1) follow the trend $\mathbf{2}>\mathbf{3}>\mathbf{1}$ revealing that decrease in Lewis acidity of iron(III) center as deduced from the electronic spectra and hence the reactivity is also expected to follow in the same trend. 
<smiles>CC(C)(C)c1cc(O)c(O)c(C(C)(C)C)c1</smiles>

$\mathrm{H}_{2} \mathrm{DBC}$<smiles>Cc1cccc(O)c1O</smiles>

$\mathrm{H}_{2}-3 \mathrm{MeCAT}$<smiles>Oc1ccccc1O</smiles>

$\mathrm{H}_{2} \mathrm{CAT}$<smiles>Oc1c(Cl)c(Cl)c(Cl)c(Cl)c1Cl</smiles>

$\mathrm{H}_{2} \mathrm{TCC}$

Scheme 4. Structures of differently substituted catechols.<smiles>O=C(O)c1cccc(C(=O)O)n1</smiles>
L1<smiles>c1ccc(-c2cccc(-c3ccccn3)n2)nc1</smiles>

L2<smiles>c1cc(-c2nc3ccccc3[nH]2)nc(-c2nc3ccccc3[nH]2)c1</smiles>

L3<smiles>c1ccc2[nH]c(CNCc3nc4ccccc4[nH]3)nc2c1</smiles>

L4

Scheme 5. Structures of the tridentate ligands.

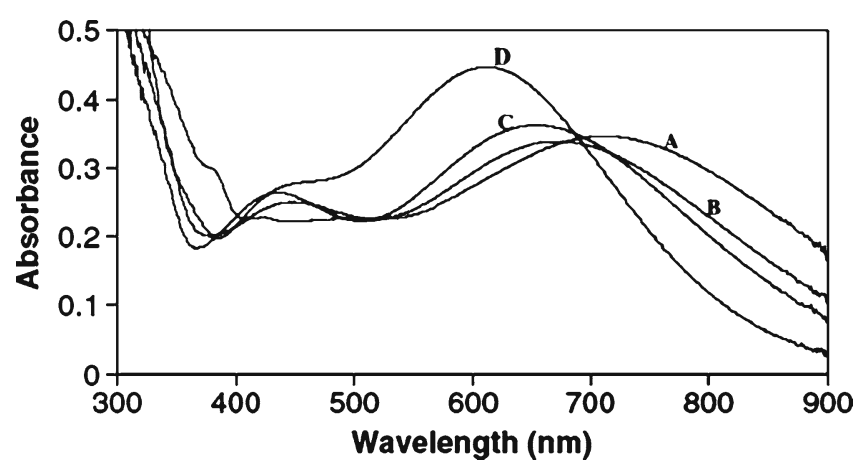

Figure 1. Electronic absorption spectra of adducts of the complex 1 generated in situ by adding equimolar amount of differently substituted catecholates in DMF solution: $[\mathrm{Fe}(\mathrm{L} 1)(\mathrm{DBC})]^{-}(\mathbf{A}),[\mathrm{Fe}(\mathrm{L} 1)(\mathrm{TBC})]^{-}(\mathbf{B}),[\mathrm{Fe}(\mathrm{L} 1)(\mathrm{CAT})]^{-}$ (C), $[\mathrm{Fe}(\mathrm{L} 1)(\mathrm{TCC})]^{-}$(D).

The ability of the complexes to catalyse the cleavage of di-tert-butylcatechol $\left(\mathrm{H}_{2} \mathrm{DBC}\right)$ was studied by treating the complexes with equimolar amount of $\mathrm{DBC}^{2-}$ in DMF in the presence of molecular oxygen. The oxidative cleavage products were identified and quantified by GC and GC-MS techniques. The iron(III)$\mathrm{DBC}^{2-}$ adducts of the present complexes were reacted with molecular oxygen to afford oxidised and oxygenated products. The rate of oxygenation of iron(III)DBC adducts of 1-3 vary in the order $\mathbf{4}>\mathbf{2}>\mathbf{3}>$ 1 (table 1), as dictated by Lewis acidity of iron(III) center. The complexes $\mathbf{1}$ and $\mathbf{3}$ yield major amount of oxygenated (intradiol cleavage product: 1, 57; 3, $10 \%$ ) products and relatively very small amount of oxidized product (quinone: 1, 2; 3, 0\%) whereas complex 2 yields major amount of oxidized product (78\%) and relatively small amount of intradiol cleavage product $(20 \%)$. This observation is very much in contrast to the major amount of the oxidative extradiol cleavage products observed for the iron(III)-DBC ${ }^{2-}$ adducts of the facially coordinating cyclic tridentate 1,4,7trimethyl-1,4,7-triazacyclononane ( $\left.\mathrm{Me}_{3} \mathrm{TACN}\right) .{ }^{41}$ This fascinating result implies that the ancillary tridentate ligand allows the both reactants (catecholate dianion and molecular oxygen) to occupy the opposite face and form a tridentate peroxo intermediate that leads to extradiol cleavage. ${ }^{41}$ Since all the present ligands are meridionally coordinated to iron(III) center, only a meridional plane is available for both the reactants and hence the two reactants are unable to form a tridentate peroxo intermediate with the available meridional sites. From these observations, it is evident that the tridentate peroxo intermediate is essential to elicit extradiol cleavage such an intermediate is formed when one of faces of the octahedron is available for reactants. Although molecular oxygen can bind to iron-center of iron(II)semiquinonate intermediate, it is constrained to be in the same plane and hence the iron(III) center acts as a conduit of electrons from substrate to molecular oxygen leading to quinone as the major product. It is interesting to note that oxidative cleavage of the catechol (instead of quinone for meridional ligands) is observed for the present complexes, which is explained by the 
Table 1. Electronic spectral, redox potential and kinetic data of iron(III) complexes and their DBC ${ }^{2-}$ adducts and cleavage products obtained upon reaction of iron(III)-DBC ${ }^{2-}$ with $\mathrm{O}_{2}$ in DMF solution.

\begin{tabular}{lcccccc}
\hline Complex & $\lambda_{\max }$, & $E_{1 / 2}(\mathrm{~V})$ & $k_{\mathrm{O} 2}\left(\mathrm{M}^{-1} \mathrm{~s}^{-1}\right)$ & \multicolumn{3}{c}{$\%$ yield } \\
\cline { 5 - 7 } & $\mathrm{nm}\left(\varepsilon_{\max }, \mathrm{M}^{-1} \mathrm{~cm}^{-1}\right)$ & & & Intradiol & Extradiol & Others \\
\hline$\left[\mathrm{Fe}(\mathrm{L} 1)\left(\mathrm{H}_{2} \mathrm{O}\right)_{2} \mathrm{Cl}\right] \mathbf{1}$ & $710(1730)$ & 0.129 & $1.80 \times 10^{-4}$ & 57.0 & 2.9 & 2.0 \\
{$\left[\mathrm{Fe}(\mathrm{L} 2) \mathrm{Cl}_{3}\right] \mathbf{2}$} & $435(1120)$ & & & & & \\
{$\left[\mathrm{Fe}(\mathrm{L} 3) \mathrm{Cl}_{3}\right] \mathbf{3}$} & $800(1370)$ & 0.390 & $2.70 \times 10^{-2}$ & 20.0 & 2.2 & 78.0 \\
{$\left[\mathrm{Fe}(\mathrm{L} 4) \mathrm{Cl}_{3}\right] \mathbf{4}$} & $520(2045)$ & & & & \\
& $790(1460)$ & 0.266 & $1.10 \times 10^{-3}$ & 9.7 & Nil & Nil \\
\hline
\end{tabular}

${ }^{\mathrm{a}} k_{\mathrm{O} 2}=k_{\text {obs }} /\left[\mathrm{O}_{2}\right]$. The solubility of $\mathrm{O}_{2}$ in $\mathrm{DMF}$ is accepted to be $4.86 \mathrm{mM}$. The kinetic data were obtained by monitoring the disappearance of the lower energy $\mathrm{DBC}^{2-}$-to-iron(III) LMCT band

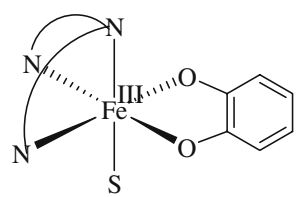

Facial tridentate

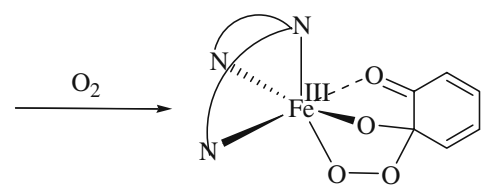

Acyl and

$\overrightarrow{\text { alkenyl migration }}$

Tridentate peroxo intermediate

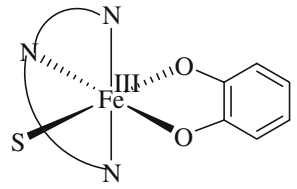

Meridional tridentate<smiles>CC1CCCCC1</smiles>

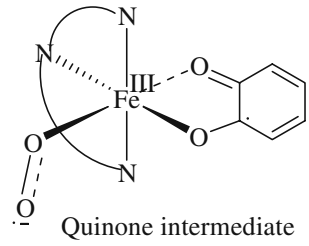

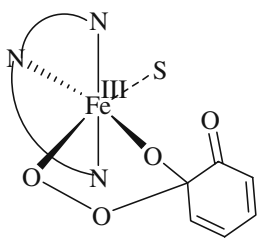

Bidentate peroxo intermediate
Mixture of intra- and extradiol cleavage products $\underset{\text { transfer }}{\stackrel{\text { Electron }}{\text { Oxidised product }}}$

Scheme 6. Proposed mechanism for the formation of tri- and bidentate peroxo intermediates.

formation of bidentate peroxo intermediate (scheme 6). The distribution of the cleavage products (formation of quinone and cleavage products) is dictated by both Lewis acidity of iron(III) center and steric bulk of ligands. The high Lewis acidity of the iron(III) center in $\mathbf{2}$ prevents the decoordination of carbonyl group from iron(III) center to form bidentate peroxo intermediate, which is essential for intradiol cleavage leading to simple electron-transfer and end up with the quinone. On the other hand, the low Lewis acidity of iron(III) center in $\mathbf{1}$ yields major amount of intradiol cleavage products due to weak binding of catecholate dianion to iron(III) center facilitating the formation of bidentate peroxo intermediate (scheme 6). Although the iron(III) center in $\mathbf{3}$ possesses a moderately low Lewis acidity, it yields lower amount of intradiol cleavage products 


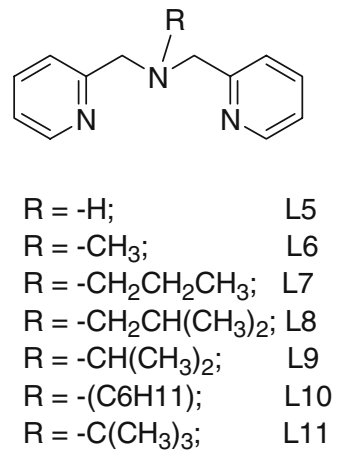

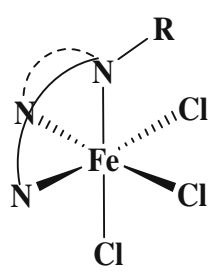

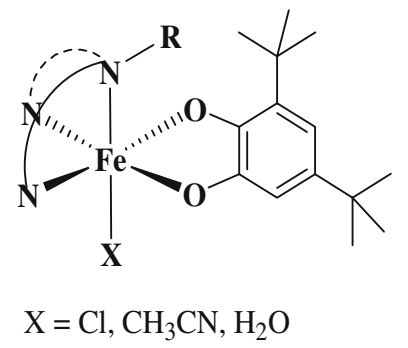

(a)

(b)

Scheme 7. Tridentate $3 \mathrm{~N}$ ligands and their facial coordination in $\left[\mathrm{Fe}(\mathrm{L}) \mathrm{Cl}_{3}\right](\mathbf{a})$ and $[\mathrm{Fe}(\mathrm{L})(\mathrm{DBC})(\mathrm{X})](\mathbf{b})$ complexes.

compared to 2 due to the bulkiness of the auxiliary ligand discouraging the substrate and oxygen binding.

\section{Iron(III) complexes of $N$-alkyl substituted bis(pyrid-2-ylmethyl)amine ligands}

A series of iron(III) complexes of the type $\left[\mathrm{Fe}(\mathrm{L}) \mathrm{Cl}_{3}\right]$, where L is variously $N$-alkyl substituted bis(pyrid-2ylmethyl)amine ligands such as bis(pyrid-2-ylmethyl) amine (L5), $\quad N, N$-bis(pyrid-2-ylmethyl)methylamine (L6), $N, N$-bis (pyrid-2-ylmethyl)- $n$-propylamine (L7), $\mathrm{N}, \mathrm{N}$-bis(pyrid-2-ylmethyl)-iso-butylamine (L8), $N, N$ bis(pyrid-2-ylmethyl)-iso-propylamine (L9), N,N-bis (pyrid-2-ylmethyl)cyclohexylamine (L10) and $N, N$-bis (pyrid-2-ylmethyl)-tert-butylamine (L11) (scheme 7) have been used to understand the role of ligand steric and electronic factors on the regioselectivity of catechol cleavage. This is the first report illustrating that a systematic variation in the ligand topology ( $N$-alkyl group) would dictate the regiospecificity (E/I, 4-6) in catechol cleavage. The X-ray crystal structures of two of the complexes $\left[\mathrm{Fe}(\mathrm{L} 5) \mathrm{Cl}_{3}\right] \mathbf{5}^{58}\left[\mathrm{Fe}(\mathrm{L} 6) \mathrm{Cl}_{3}\right] \mathbf{6}$ and $\left[\mathrm{Fe}(\mathrm{L} 7) \mathrm{Cl}_{3}\right] 7$ have been determined to demonstrate the availability of facial coordination positions for the binding of substrate and molecular oxygen (figure 2). The $\mathrm{Fe}-\mathrm{N}_{\mathrm{amine}}$ bond length increases with increasing the bulkiness of $N$-alkyl group, which facilitates stronger binding of catechol to iron(III) center. ${ }^{48,58-60}$ In $\left[\mathrm{Fe}(\mathrm{L} 9)(\mathrm{TCC})\left(\mathrm{NO}_{3}\right)\right]$ 9a one of the octahedral face of iron(III) center is coordinated by the tridentate ligand and the remaining octahedral sites are occupied by catecholate dianion and one of the oxygen atoms of nitrate ion (figure 3). This clearly explains the possibility of $\mathrm{O}_{2}$ attack on iron(III) by replacing the $\mathrm{NO}^{3-}$ group leading to formation of tridentate peroxo intermediate during the catalytic reaction.

The adducts $[\mathrm{Fe}(\mathrm{L})(\mathrm{DBC})(\mathrm{Cl})]$ generated in $\mathrm{DCM}$ show two visible features in the region of 465-530 and $690-860 \mathrm{~nm}$ (table 2) and both these LMCT bands exhibit remarkable dependence on the $N$-alkyl substituent in the $3 \mathrm{~N}$ ligand. ${ }^{25-27,53-55}$ Their energies decrease in the order: $5>6>7 \geq 8>9 \geq 10$ $>$ 11, reflecting the increase in Lewis acidity of the iron(III) center along the series, as modified by the $\mathrm{N}$-alkyl groups. Also, upon removing the coordinated chloride ions by treating the complexes 5-11 in DCM with three equivalents of $\mathrm{AgClO}_{4} \cdot \mathrm{H}_{2} \mathrm{O}\left(\mathrm{CH}_{3} \mathrm{CN}\right)$ and then adding one equivalent of $\mathrm{DBC}^{2-}$ to generate $[\mathrm{Fe}(\mathrm{L})(\mathrm{DBC})(\mathrm{Sol})]^{+}$species $\left(\mathrm{Sol}=\mathrm{H}_{2} \mathrm{O} / \mathrm{CH}_{3} \mathrm{CN}\right)$ both the high- and low-energy bands are shifted significantly (20-110 nm) to lower energies suggesting an increase in Lewis acidity of the iron(III) center and hence a stronger iron(III)-catecholate interaction.

The $E_{1 / 2}$ values of $\mathrm{Fe}^{\mathrm{III}} / \mathrm{Fe}^{\mathrm{II}}$ redox potentials (table 2) follow the trend $\mathbf{5}>\mathbf{6}>\mathbf{7}>\mathbf{8}<\mathbf{9}>$ $10 \approx 11$ reflecting a decrease in Lewis acidity of iron(III) center along this series. This trend is in contrast to that observed in electronic spectra, obviously because the coordinated chloride ions compensate for the increase in positive charge on iron effected by the sterically hindering $N$-alkyl groups. On adding one equivalent of $\mathrm{H}_{2} \mathrm{DBC}$ to 1-7 in DCM solution a new wave appears in the CV and DPV responses, which corresponds to DBSQ/DBC ${ }^{2-}$ couple $^{53-55,58-62}$ of $[\mathrm{Fe}(\mathrm{L})(\mathrm{DBC})(\mathrm{Cl})]$ species generated. On adding two equivalents of $\mathrm{Et}_{3} \mathrm{~N}$ to deprotonate the catechol the reduction current of this couple increases and the $\mathrm{Fe}^{\mathrm{III}} / \mathrm{Fe}^{\mathrm{II}}$ redox wave tend to vanish completely, which is expected ${ }^{53-55,58-62}$ to be shifted to a more negative potential due to chelation of $\mathrm{DBC}^{2-}$. Also, the redox potential of $\mathrm{DBSQ} / \mathrm{DBC}^{2-}$ couple of $[\mathrm{Fe}(\mathrm{L})(\mathrm{DBC})(\mathrm{Cl})]$ 

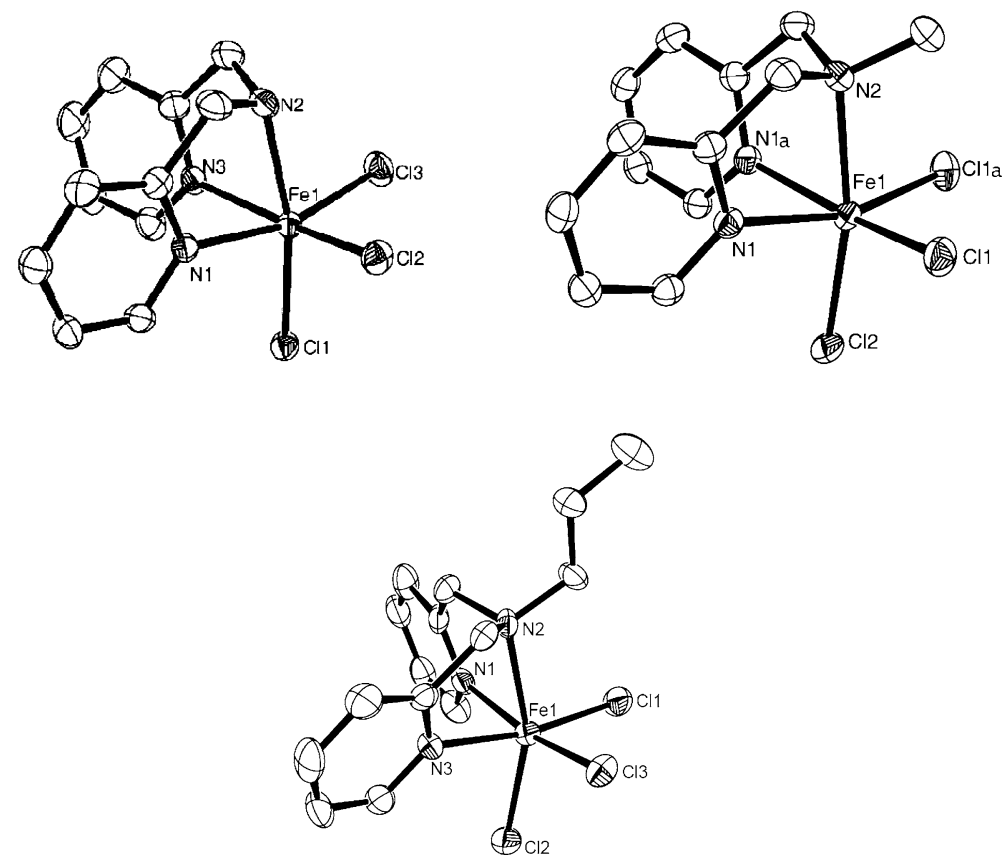

Figure 2. ORTEP diagram of complex 5,6 and 7 showing $40 \%$ probability thermal ellipsoids and the labelling scheme for selected atoms. All hydrogen atoms are omitted for clarity.

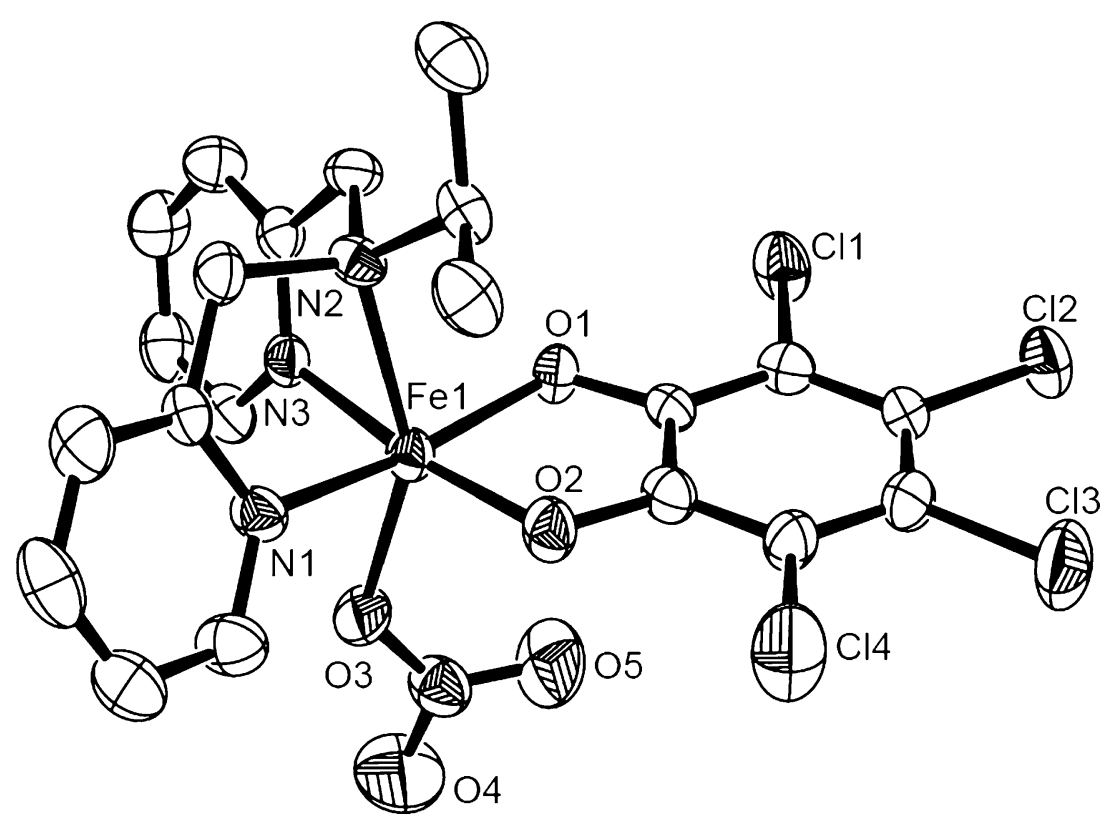

Figure 3. ORTEP diagram of complex 9a showing 50\% probability thermal ellipsoids and the labelling scheme for selected atoms. All hydrogen atoms are omitted for clarity.

species is observed in the range $-0.075--0.009 \mathrm{~V}$, which is less negative than that of free DBSQ/DBC ${ }^{2-}$ couple $\left(E_{\mathrm{pc}},-1.34 \mathrm{~V}\right.$ vs. SCE). This confirms the enhanced covalency of iron-catecholate interaction and stabilization of semiquinone radical of coordinated $\mathrm{DBC}^{2-}$ anion towards oxidation and is consistent with the above spectral results. The $\mathrm{Fe}^{\mathrm{III}} / \mathrm{Fe}^{\mathrm{II}}$ redox waves of $\left[\mathrm{Fe}(\mathrm{L})(\mathrm{Sol})_{3}\right]^{3+}$ species from $\mathbf{5 - 1 1}$ are shifted to 
Table 2. Electonic spectral and redox potential data of iron(III) complexes ${ }^{\mathrm{a}}$ and their $\mathrm{DBC}^{2-}$ adducts $^{\mathrm{b}}$ in DCM solution.

\begin{tabular}{|c|c|c|c|c|c|}
\hline \multirow[t]{2}{*}{ Complex } & \multicolumn{2}{|c|}{$\lambda_{\max }, \mathrm{nm}\left(\varepsilon_{\max }, \mathrm{M}^{-1} \mathrm{~cm}^{-1}\right)$} & \multicolumn{2}{|c|}{$E_{1 / 2}(\mathrm{~V})^{\mathrm{c}}$} & \multirow[t]{2}{*}{ Redox preocess } \\
\hline & {$[\mathrm{Fe}(\mathrm{L})(\mathrm{DBC}) \mathrm{Cl}]$} & {$[\mathrm{Fe}(\mathrm{L})(\mathrm{DBC})(\mathrm{Sol})]^{+}$} & {$\left[\mathrm{Fe}(\mathrm{L}) \mathrm{Cl}_{3}\right]$} & {$\left[\mathrm{Fe}(\mathrm{L})(\mathrm{Sol})_{3}\right]$} & \\
\hline \multirow[t]{2}{*}[\mathrm{Fe}(\mathrm{L}5)\mathrm{Cl}_{3}]{$\mathbf{5}$} & $820(3260)$ & $839(2650)$ & -0.206 & 0.157 & $\mathrm{Fe}^{\mathrm{III}} \rightarrow \mathrm{Fe}^{\mathrm{II}}$ \\
\hline & $505(1970)$ & $549(2170)$ & -0.075 & 0.313 & $\mathrm{DBSQ} \rightarrow \mathrm{DBC}$ \\
\hline \multirow[t]{2}{*}[\mathrm{Fe}(\mathrm{L}6)\mathrm{Cl}_{3}]{6} & $848(1970)$ & $737(2430)$ & -0.257 & 0.209 & $\mathrm{Fe}^{\mathrm{III}} \rightarrow \mathrm{Fe}^{\mathrm{II}}$ \\
\hline & $508(1240)$ & $607(1870)$ & -0.023 & 0.407 & $\mathrm{DBSQ} \rightarrow \mathrm{DBC}$ \\
\hline \multirow[t]{2}{*}[\mathrm{Fe}(\mathrm{L}7)\mathrm{Cl}_{3}]{7} & $852(2700)$ & $795(2710)$ & -0.287 & 0.125 & $\mathrm{Fe}^{\mathrm{III}} \rightarrow \mathrm{Fe}^{\mathrm{II}}$ \\
\hline & $512(1753)$ & $619(1940)$ & -0.045 & 0.413 & $\mathrm{DBSQ} \rightarrow \mathrm{DBC}$ \\
\hline \multirow[t]{2}{*}[\mathrm{Fe}(\mathrm{L}8)\mathrm{Cl}_{3}]{$\mathbf{8}$} & $852(3290)$ & $893(2000)$ & -0.299 & 0.181 & $\mathrm{Fe}^{\mathrm{III}} \rightarrow \mathrm{Fe}^{\mathrm{II}}$ \\
\hline & $519(2160)$ & $581(1500)$ & -0.009 & 0.415 & $\mathrm{DBSQ} \rightarrow \mathrm{DBC}$ \\
\hline \multirow[t]{2}{*}[\mathrm{Fe}(\mathrm{L}9)\mathrm{Cl}_{3}]{9} & $856(1430)$ & $899(1830)$ & -0.280 & 0.157 & $\mathrm{Fe}^{\mathrm{III}} \rightarrow \mathrm{Fe}^{\mathrm{II}}$ \\
\hline & $519(1095)$ & $585(1550)$ & -0.019 & 0.415 & $\mathrm{DBSQ} \rightarrow \mathrm{DBC}$ \\
\hline \multirow[t]{2}{*}[\mathrm{Fe}(\mathrm{L}10)\mathrm{Cl}_{3}]{$\mathbf{1 0}$} & $856(2380)$ & $910(2600)$ & -0.323 & 0.139 & $\mathrm{Fe}^{\mathrm{III}} \rightarrow \mathrm{Fe}^{\mathrm{II}}$ \\
\hline & $531(1740)$ & $588(1820)$ & -0.051 & 0.411 & $\mathrm{DBSQ} \rightarrow \mathrm{DBC}$ \\
\hline \multirow[t]{2}{*}[\mathrm{Fe}(\mathrm{L}11)\mathrm{Cl}_{3}]{$\mathbf{1 1}$} & $859(1440)$ & $942(1820)$ & -0.324 & 0.125 & $\mathrm{Fe}^{\mathrm{III}} \rightarrow \mathrm{Fe}^{\mathrm{II}}$ \\
\hline & $523(1040)$ & 605 (1830) & -0.039 & - & $\mathrm{DBSQ} \rightarrow \mathrm{DBC}$ \\
\hline
\end{tabular}

${ }^{\mathrm{a}}$ Concentration of iron(III) complexes, $2 \times 10^{-4} \mathrm{M}$

${ }^{\mathrm{b}}$ The ratio of added ligand to iron(III) complexes was 1:1; the anions were generated by adding 2 equivalents of triethylamine

${ }^{\mathrm{c}}$ Potntial measured vs. $\mathrm{Ag}(\mathrm{s}) / \mathrm{Ag}^{+}$(0.01 M, 0.10 M TBAP); add $0.544 \mathrm{~V}$ to convert to NHE

Table 3. Kinetic data ${ }^{\mathrm{a}}$ and cleavage products obtained upon reaction of iron(III)-DBC adducts with $\mathrm{O}_{2}$.

\begin{tabular}{|c|c|c|c|c|c|c|}
\hline \multirow[t]{3}{*}{ Complex } & \multirow{3}{*}{$\begin{array}{c}k_{\mathrm{O} 2}\left(\mathrm{M}^{-1} \mathrm{~s}^{-1}\right) \\
\text { in DMF }\end{array}$} & \multicolumn{5}{|c|}{$[\mathrm{Fe}(\mathrm{L})(\mathrm{DBC})(\mathrm{Sol})]^{+}$} \\
\hline & & \multirow{2}{*}{$\begin{array}{c}k_{\mathrm{O} 2}\left(\mathrm{M}^{-1} \mathrm{~s}^{-1}\right) \\
\text { in } \mathrm{DMF}\end{array}$} & \multirow{2}{*}{$\begin{array}{c}k_{\mathrm{O} 2}\left(\mathrm{M}^{-1} \mathrm{~s}^{-1}\right) \\
\text { in } \mathrm{DCM}\end{array}$} & \multicolumn{3}{|c|}{ Cleavage products in $\%$} \\
\hline & & & & Extradiol & Intradiol & $\mathrm{E} / \mathrm{I}$ ratio \\
\hline$\left[\mathrm{Fe}(\mathrm{L} 5) \mathrm{Cl}_{3}\right]$ & $17.00 \times 10^{-3}$ & $4.08 \times 10^{-2}$ & 0.162 & 26.7 & 18.6 & 1.4 \\
\hline$\left[\mathrm{Fe}(\mathrm{L6}) \mathrm{Cl}_{3}\right]$ & $3.10 \times 10^{-3}$ & $1.01 \times 10^{-2}$ & 0.152 & 38.7 & 41.0 & 0.9 \\
\hline$\left[\mathrm{Fe}(\mathrm{L} 7) \mathrm{Cl}_{3}\right]$ & $1.65 \times 10^{-3}$ & $1.24 \times 10^{-2}$ & 0.159 & 37.8 & 11.7 & 3.2 \\
\hline$\left[\mathrm{Fe}(\mathrm{L} 8) \mathrm{Cl}_{3}\right]$ & $2.83 \times 10^{-3}$ & $0.85 \times 10^{-2}$ & 0.311 & 59.5 & 14.4 & 4.1 \\
\hline$\left[\mathrm{Fe}(\mathrm{L} 9) \mathrm{Cl}_{3}\right]$ & $1.94 \times 10^{-3}$ & $1.39 \times 10^{-2}$ & 0.188 & 68.0 & 11.1 & 6.1 \\
\hline$\left[\mathrm{Fe}(\mathrm{L} 10) \mathrm{Cl}_{3}\right]$ & $3.74 \times 10^{-3}$ & $0.96 \times 10^{-2}$ & 0.194 & 64.1 & 12.8 & 5.0 \\
\hline$\left[\mathrm{Fe}(\mathrm{L} 11) \mathrm{Cl}_{3}\right]$ & $2.82 \times 10^{-3}$ & $3.03 \times 10^{-2}$ & 0.376 & 34.8 & 27.5 & 1.3 \\
\hline
\end{tabular}

${ }^{\mathrm{a}} k_{\mathrm{O} 2}=k_{\text {obs }} /\left[\mathrm{O}_{2}\right]$. The solubility of $\mathrm{O}_{2}$ in DMF is accepted to be $4.86 \mathrm{mM}$; in DCM, $5.80 \mathrm{mM}$ at $25^{\circ} \mathrm{C}$. The kinetic data were obtained by monitoring the disappearance of the lower energy $\mathrm{DBC}^{2-}$-to-iron(III) LMCT band

potentials enormously more positive $(0.412-0.480 \mathrm{~V})$ than those observed for the corresponding $\left[\mathrm{Fe}(\mathrm{L}) \mathrm{Cl}_{3}\right]$ complexes, as expected. Hence the electron-transfer from the coordinated catecholate adducts to dioxygen is thermodynamically less favourable in the solvated complexes than in the chloro complexes, obviously due to the higher Lewis acidity of the iron(III) centers. Very recently, Solomon et al. have described ${ }^{35}$ the nature of such an electron transfer, $\mathrm{O}_{2}$ is reduced to a superoxide while the catecholate is at the semiquinone level at the transition state.
The second order reaction rate constants $\left(k_{\mathrm{O} 2}\right.$, $\left.0.85-4.08 \times 10^{-2} \mathrm{M}^{-1} \mathrm{~s}^{-1}\right)$ for $[\mathrm{Fe}(\mathrm{L})(\mathrm{DBC})(\mathrm{Sol})]^{+}$ adducts derived from 5-11 in DMF are 5-10 fold higher than those $\left(0.17-1.70 \times 10^{-2} \mathrm{M}^{-1} \mathrm{~s}^{-1}\right)$ for $[\mathrm{Fe}(\mathrm{L})(\mathrm{DBC})(\mathrm{Cl})]$ adducts in the same solvent (table 3). This is expected of the higher Lewis acidity $^{63}$ of the iron(III) centre in $[\mathrm{Fe}(\mathrm{L})(\mathrm{DBC})(\mathrm{Sol})]^{+}$ adducts, which favours catecholate and dioxygen binding. Upon introducing bulky alkyl groups near the donor atoms in the heterocyclic ring systems ${ }^{28,64}$ as in $\left[\mathrm{Fe}\left(\mathrm{Tp}^{i \mathrm{pr}, t \mathrm{Bu}}\right)(\mathrm{DBC})\right]^{+}$and $[\mathrm{Fe}(6-\mathrm{MeTPA})(\mathrm{DBC})]^{+}$, 


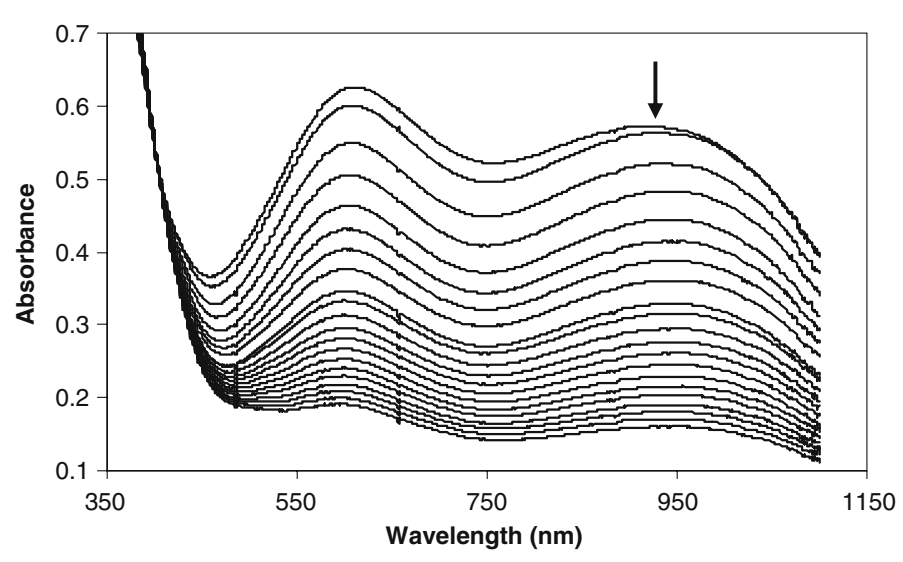

Figure 4. Progress of the reaction of adduct $[\mathrm{Fe}(\mathrm{L} 11)(\mathrm{DBC})(\mathrm{Sol})]^{+}$with $\mathrm{O}_{2}$ in $\mathrm{DCM}$ solution. The disappearance of the $\mathrm{DBC}^{2-}$-to-iron(III) charge-transfer band is monitored.

catechol and dioxygen are discouraged from binding to iron(III) centre leading to a decrease in dioxygenase activity of the complexes. On the other hand, dioxygen could approach iron(III) center of the present $[\mathrm{Fe}(\mathrm{L})(\mathrm{DBC})(\mathrm{Sol})]^{+}$adducts opposite to the sterically hindered $N$-alkyl groups (cf. crystal structure of 9a). Interestingly, the reaction rates for $[\mathrm{Fe}(\mathrm{L})(\mathrm{DBC})(\mathrm{Sol})]^{+}$ complexes in DCM are 10-130 fold higher than in DMF solvent (figure 4). Obviously, the displacement of coordinated solvent in the adduct by dioxygen in non-coordinating solvent DCM is more facile than that of the solvent by dioxygen in the DMF. The plot of $\log \left(k_{\mathrm{O} 2}\right)$ vs. energy of the low-energy catecholate-to-metal CT band is linear, which is in line with the trend in Lewis acidity of iron(III) centres (cf. above). The adducts $[\mathrm{Fe}(\mathrm{L} 8)(\mathrm{DBC})(\mathrm{Sol})]^{+}$ and $[\mathrm{Fe}(\mathrm{L} 11)(\mathrm{DBC})(\mathrm{Sol})]^{+}$exhibit a positive deviation from the straight line illustrating that in addition to the high Lewis acidity of iron(III) centres the bulkiness and orientation of $N$-alkyl groups of the adducts enhances the reaction rate (cf. above). ${ }^{65,66}$ The reactivity of the present adducts is explained by invoking a two states reaction pathway, which involves a spin-inversion process $^{67}$ from spin-sextet state $(\mathrm{S}=5 / 2)$ in $(\mathrm{L}) \mathrm{Fe}^{\mathrm{III}}$ $\mathrm{Cat}^{2-}$ to the upper lying spin-doublet $(\mathrm{S}=1 / 2)$ state in (L)Fe $\mathrm{Fe}^{\mathrm{II}}-\mathrm{SQ}$ upon $\mathrm{O}_{2}$ approaching the iron(III) centre. As $\mathrm{O}_{2}$ approaches the iron(III)-catecholate adduct, the ligand field strength increases causing spin-pairing leading to spin-inversion and formation of $\mathrm{Fe}$ (II)-SQ state. Thus for the present complexes both the Lewis acidity and ligand steric demand enhance the reactivity of complexes towards dioxygenation of catechol substrates.

All the present complexes also afford major amounts of intradiol cleavage products and smaller amounts of extradiol (1.5-5\%) products in DMF solvent. On the other hand, extradiol cleavage products are isolated in $13-22 \%$ yield (the results are not shown here) for the adducts $[\mathrm{Fe}(\mathrm{L})(\mathrm{DBC})(\mathrm{Sol})]^{+}$generated in DMF. It is clear that the presence of a vacant or solventcoordinated site at cis-position to $\mathrm{Fe}-\mathrm{O}_{\text {cat }}$ bond on iron(III) centre of the catecholate adducts is essential for dioxygen attack to achieve extradiol cleavage products and that a coordinated chloride ion in the adduct $[\mathrm{Fe}(\mathrm{L})(\mathrm{DBC}) \mathrm{Cl}]$ is difficult to be replaced by dioxygen to afford extradiol cleavage products. Thus it is remarkable that all the solvent coordinated adducts $[\mathrm{Fe}(\mathrm{L})(\mathrm{DBC})(\mathrm{Sol})]^{+}$generated in DCM solvent show enhanced yields of extradiol cleavage products (26.7 $68.0 \%$; table 3 ). Further, the catecholate adducts derived from 8-10 show the highest yield of extradiol cleavage products $(59.5-68.0 \%)$ with the extradiol to intradiol cleavage product selectivity $(E / I)$ being approximately $6: 1$ while the adduct derived from 7 shows a lower selectivity $(E / I, 4: 1)$ (figure 5 ). On the other hand, the adducts derived from $\mathbf{5 ,} \mathbf{6}$ and $\mathbf{1 1}$ show $26.7-38.7 \%$ of extradiol cleavage products with much lower selectivity $(E / I, \sim 1: 1)$. The facially coordinated $3 \mathrm{~N}$ ligands in the present complexes allow the two reactants (molecular oxygen and catechol) to occupy the opposite face of the iron coordination sphere thereby bringing them in close proximity and in proper orientation to form tridentate peroxo intermediate, ${ }^{68}$ which on alkenyl migration gives extradiol cleavage products and on acyl migration yields intradiol cleavage products. Very recently, this is confirmed by trapping three different intermediates in a single enzyme, tridentate peroxo intermediate is one among them and is more intriguing one. ${ }^{21}$ In order to address the alkenyl and acyl migrations, one would understand examples of hydroperoxide rearrangements in organic chemistry. ${ }^{69-71}$ It is suggested that the acyl and alkenyl migrations of a common hydroperoxide intermediate is controlled by the conformation of the bound intermediate and hence the precise positioning of the $\mathrm{O}-\mathrm{O}$ bond. So it emerges from the present study that the $N$-alkyl groups $n$-propyl, iso-butyl, iso-propyl and cyclohexyl in the $3 \mathrm{~N}$ ligand complexes facilitate alkenyl migration while the $\mathrm{H}$, methyl and tert-butyl groups favour both alkenyl and acyl migrations (scheme 8).

\section{Iron(III) complexes of terminal $N$-alkyl// substituted $3 \mathrm{~N}$ ligands}

A series of 1:1 iron(III) complexes of sterically hindered and systematically modified tridentate $3 \mathrm{~N}$ donor 


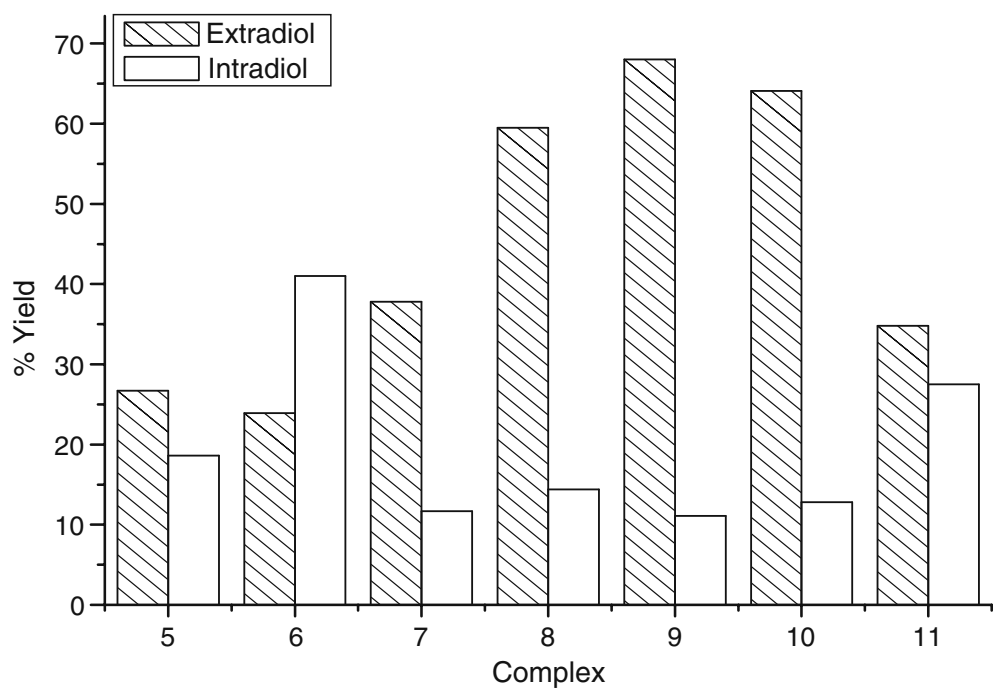

Figure 5. Plot of complexes versus \% yield of oxidative cleavage of catechol in DCM.

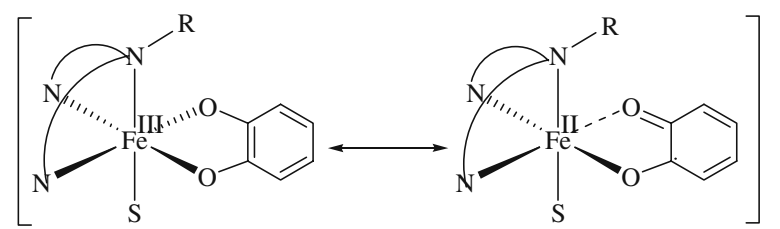

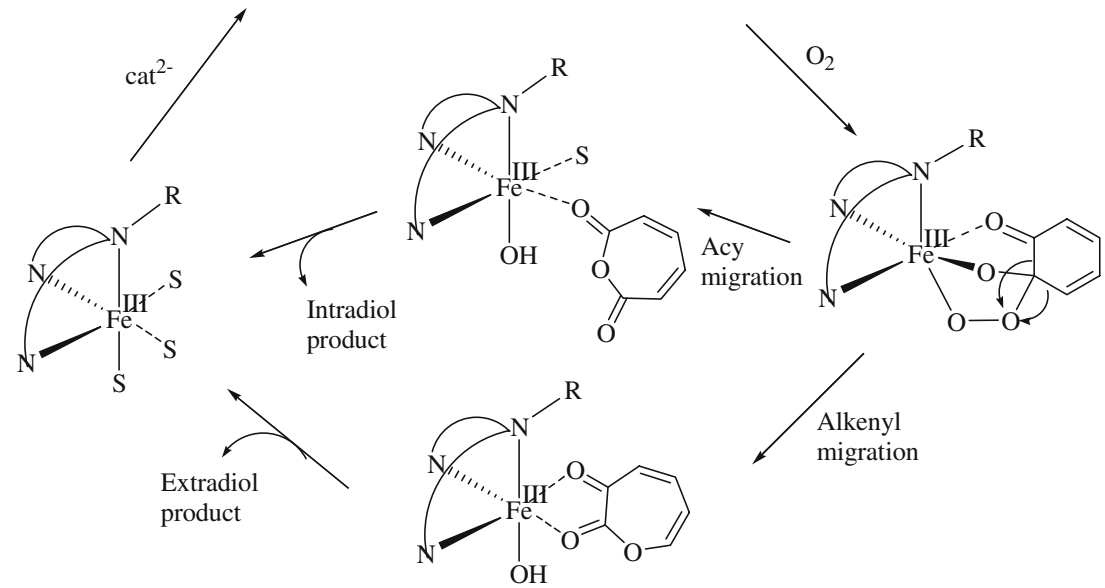

Scheme 8. Proposed mechanism for intra- and extradiol cleavage.<smiles>[R]N([R])CCNCc1ccccn1</smiles>

$$
\begin{array}{lr}
\mathrm{R}=-\mathrm{H}, \mathrm{R}^{\prime}=-\mathrm{CH}_{3} ; & \mathrm{L} 12 \\
\mathrm{R}=-\mathrm{H}, \mathrm{R}^{\prime}=-\mathrm{CH}_{2} \mathrm{CH}_{3} ; & \mathrm{L} 13 \\
\mathrm{R}=-\mathrm{H}, \mathrm{R}^{\prime}=-\mathrm{CH}_{2}\left(\mathrm{C}_{6} \mathrm{H}_{5}\right) ; \mathrm{L} 14 \\
\mathrm{R}=-\mathrm{H}, \mathrm{R}^{\prime}=-\left(\mathrm{C}_{6} \mathrm{H}_{5}\right) ; & \mathrm{L} 15 \\
\mathrm{R}=-\mathrm{CH}_{3}, \mathrm{R}^{\prime}=-\mathrm{CH}_{3} ; & \mathrm{L} 16
\end{array}
$$<smiles>[R]N(CCN(C)C)Cc1ccccn1</smiles>

$$
\begin{array}{lr}
\mathrm{R}=-\mathrm{CH}_{3} ; \quad \mathrm{L} 17 \\
\mathrm{R}=-\mathrm{CH}_{2} \mathrm{CH}_{3} ; \quad \mathrm{L} 18 \\
\mathrm{R}=-\mathrm{CH}_{2}\left(\mathrm{C}_{6} \mathrm{H}_{5}\right) ; \mathrm{L} 19
\end{array}
$$

Scheme 9. Linear tridentate ligands employed. 

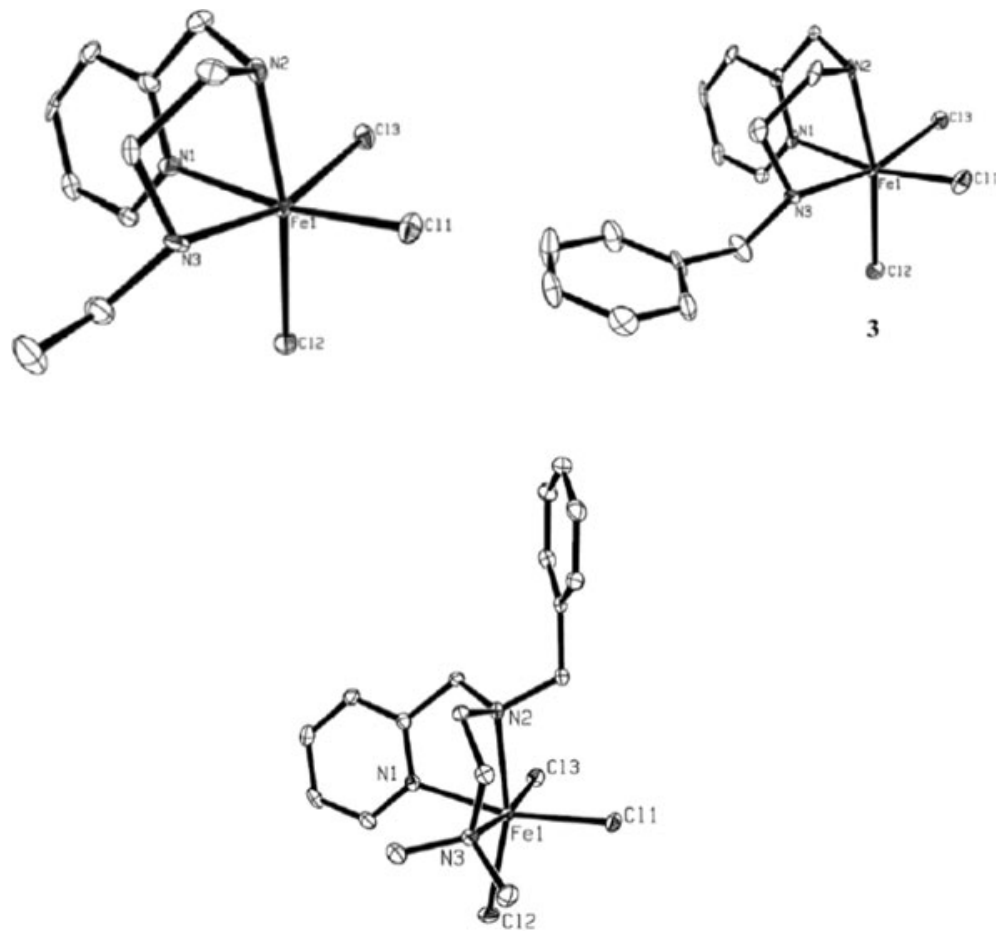

Figure 6. ORTEP diagram of complex 13, 14 and 19 showing 50\% probability thermal ellipsoids and the labelling scheme for selected atoms. All hydrogen atoms are omitted for clarity.

ligands have been studied as functional models for extradiol-cleaving catechol dioxygenases. All these are of the type $\left[\mathrm{Fe}(\mathrm{L}) \mathrm{Cl}_{3}\right]$, where $\mathrm{L}$ is $N$-methyl- $N^{\prime}$-(pyrid2-ylmethyl)ethylenediamine (L12), $N$-ethyl- $N^{\prime}$-(pyrid2-ylmethyl)ethylenediamine (L13), $N$-benzyl- $N^{\prime}$-(pyrid2-ylmethyl)ethylenediamine (L14), $N$-phenyl- $N$ '-(pyrid2-ylmethyl)ethylenediamine (L15), $N, N$-dimethyl- $N^{\prime}-$ (pyrid-2-ylmethyl)ethylenediamine (L16), $N^{\prime}$-methyl$N^{\prime}$-(pyrid-2-ylmethyl)- $N, N$-dimethylethylenediamine (L17), $\quad N^{\prime}$-ethyl- $N^{\prime}$-(pyrid-2-ylmethyl)- $N, N$-dimethylethylenediamine (L18) and $N^{\prime}$-benzyl- $N^{\prime}$-(pyrid-2ylmethyl)- $N, N$-dimethylethylenediamine (L19) (scheme 9). The molecular structures of complexes 13, 14 and 19 (figure 6) demonstrate that the tridentate ligands are coordinated to iron(III) center in a facial fashion and the remaining sites are completed by three chloride. Upon increasing the bulkiness on the terminal $\mathrm{N}$-atom of the ethylenediamine moiety, the $\mathrm{Fe}-\mathrm{N}_{\text {amine }}$ bond length increases as observed previously. ${ }^{48,58-60}$ A similar increase in bond length is observed in complex 19, which is obviously due to the lone pair orbital not oriented exactly towards the iron(III) orbital rendering the $\mathrm{Fe}-\mathrm{N}_{\mathrm{amine}}$ bond longer.
Two moderately intense visible bands (400-520, 600-865 nm; table 4) appear on adding catechols pretreated with two equiv. of $\mathrm{Et}_{3} \mathrm{~N}$ to the iron(III) complexes 12-19 in DMF solution. ${ }^{53-55,58-62}$ The positions of both the low- and high-energy bands depend on the nature of substituents on the catecholate ring and are shifted to higher energies when the substituents are varied from electron-donating to electron-withdrawing. In DMF solvent both the low- and high-energy LMCT bands exhibit a remarkable dependence on the number of $N$-alkyl substituents in the complexes of $3 \mathrm{~N}$ ligands and their energies decrease in the order: $12>13>$ $14>16>17 \geq 18>19$ and thus, on increasing the number of $N$-alkyl substituents along the above series, the lower energy band shifts from 781 to 810 to $848 \mathrm{~nm}$ in DMF solvent. The decrease in energies of the bands reflects the increase in Lewis acidity of the iron(III) center along the above series, as modified by the $N$-alkyl groups.

The iron(III) complexes 12-19 exhibit redox waves at negative potentials in cyclic voltammetry, which are assigned to $\mathrm{Fe}^{\mathrm{III}} / \mathrm{Fe}^{\mathrm{II}}$ couple. The $E_{1 / 2}$ values of $\mathrm{Fe}^{\mathrm{III}} / \mathrm{Fe}^{\mathrm{II}}$ redox potentials $(-0.402$ to $-0.276 \mathrm{~V}$, table 4) reflect a variation in Lewis acidity of the 
Table 4. Electonic spectral and redox potential data of iron(III) complexes and their $\mathrm{DBC}^{2-}$ adducts $^{\mathrm{b}}$ in $\mathrm{DMF}$ solution.

\begin{tabular}{|c|c|c|c|}
\hline \multirow[t]{2}{*}{ Complex $^{\mathrm{a}}$} & $\lambda_{\max }, \operatorname{nm}\left(\varepsilon_{\max }, \mathrm{M}^{-1} \mathrm{~cm}^{-1}\right)$ & $E_{1 / 2}(\mathrm{~V})$ & \multirow[t]{2}{*}{ Redox preocess } \\
\hline & {$[\mathrm{Fe}(\mathrm{L})(\mathrm{DBC}) \mathrm{Cl}]$} & {$\left[\mathrm{Fe}(\mathrm{L})(\mathrm{Sol})_{3}\right]$} & \\
\hline \multirow[t]{2}{*}[\mathrm{Fe}(\mathrm{L}12)\mathrm{Cl}_{3}]{$\mathbf{1 2}$} & $781(2185)$ & 0.135 & $\mathrm{Fe}^{\mathrm{III}} \rightarrow \mathrm{Fe}^{\mathrm{II}}$ \\
\hline & 491 (1300) & & $\mathrm{DBSQ} \rightarrow \mathrm{DBC}$ \\
\hline \multirow{2}{*}[\mathrm{Fe}(\mathrm{L}13)\mathrm{Cl}_{3}]{$\mathbf{1 3}$} & $786(2365)$ & 0.139 & $\mathrm{Fe}^{\mathrm{III}} \rightarrow \mathrm{Fe}^{\mathrm{II}}$ \\
\hline & 464 (2180) & & $\mathrm{DBSQ} \rightarrow \mathrm{DBC}$ \\
\hline \multirow[t]{2}{*}[\mathrm{Fe}(\mathrm{L}14)\mathrm{Cl}_{3}]{$\mathbf{1 4}$} & 789 (2170) & 0.151 & $\mathrm{Fe}^{\mathrm{III}} \rightarrow \mathrm{Fe}^{\mathrm{II}}$ \\
\hline & 481 (1675) & & $\mathrm{DBSQ} \rightarrow \mathrm{DBC}$ \\
\hline \multirow{2}{*}[\mathrm{Fe}(\mathrm{L}15)\mathrm{Cl}_{3}]{$\mathbf{1 5}$} & $850(2890)$ & - & $\mathrm{Fe}^{\mathrm{III}} \rightarrow \mathrm{Fe}^{\mathrm{II}}$ \\
\hline & $515(1870)$ & & $\mathrm{DBSQ} \rightarrow \mathrm{DBC}$ \\
\hline \multirow[t]{2}{*}[\mathrm{Fe}(\mathrm{L}16)\mathrm{Cl}_{3}]{16} & $815(2820)$ & 0.137 & $\mathrm{Fe}^{\mathrm{III}} \rightarrow \mathrm{Fe}^{\mathrm{II}}$ \\
\hline & $500(1890)$ & & $\mathrm{DBSQ} \rightarrow \mathrm{DBC}$ \\
\hline \multirow{2}{*}[\mathrm{Fe}(\mathrm{L}17)\mathrm{Cl}_{3}]{17} & 848 (2425) & 0.148 & $\mathrm{Fe}^{\mathrm{III}} \rightarrow \mathrm{Fe}^{\mathrm{II}}$ \\
\hline & $510(1735)$ & & $\mathrm{DBSQ} \rightarrow \mathrm{DBC}$ \\
\hline \multirow{2}{*}[\mathrm{Fe}(\mathrm{L}18)\mathrm{Cl}_{3}]{$\mathbf{1 8}$} & 848 (1990) & 0.134 & $\mathrm{Fe}^{\mathrm{III}} \rightarrow \mathrm{Fe}^{\mathrm{II}}$ \\
\hline & $510(1570)$ & & $\mathrm{DBSQ} \rightarrow \mathrm{DBC}$ \\
\hline \multirow[t]{2}{*}[\mathrm{Fe}(\mathrm{L}19)\mathrm{Cl}_{3}]{19} & $862(2310)$ & 0.156 & \\
\hline & $518(1750)$ & & \\
\hline
\end{tabular}

${ }^{\mathrm{a}}$ Concentration of iron(III) complexes, $2 \times 10^{-4} \mathrm{M}$

${ }^{\mathrm{b}}$ The ratio of added ligand to iron(III) complexes was 1:1; the anions were generated by adding 2 equivalents of triethylamine

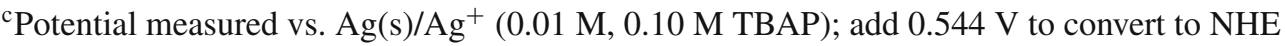

iron(III) center along this series $\mathbf{1 2}<\mathbf{1 3}<\mathbf{1 4}<$ $16<17>18>19$ in DMF. Upon replacement of the $N$-methyl group in the terminal nitrogen donor in $\mathbf{1 2}$ by the more sterically demanding $N$-ethyl group in 13, and that of $N$-ethyl group by the more sterically demanding $N$-benzyl group in 14, the lone pair orbital of the nitrogen atom becomes improperly oriented towards the iron(III) orbital leading to an increase in positive charge on iron(III) and hence a higher $\mathrm{Fe}^{\mathrm{III}} / \mathrm{Fe}^{\mathrm{II}}$ redox potential on $\mathbf{1 3}$ and 14. Similarly, the incorporation of two methyl groups as in $\mathbf{1 6}$ enhances the $E_{1 / 2}$ value, which is consistent with the increase in the $\mathrm{Fe}-\mathrm{N}$ distance of the terminal nitrogen atom from 2.229(5) $\AA$ in $\mathbf{1 3}$ to 2.290(5) $\AA$ in $\mathbf{1 6}$. In contrast to this trend, the increase in bulkiness of the $N$-alkyl group on the central nitrogen atom of $3 \mathrm{~N}$ ligands leads to a decrease in $E_{1 / 2}$ value of $\mathrm{Fe}^{\mathrm{III}} / \mathrm{Fe}^{\mathrm{II}}$ redox potential illustrating the increase in positive charge on iron(III) center $\left(\mathrm{Fe}-\mathrm{N}_{\mathrm{amine}}\right.$ distance increases from 2.181(5) $\AA$ in 16 to $2.299(2) \AA$ in 19) is compensated by the stronger coordination of chloride ion. The $\mathrm{Fe}^{\mathrm{III}} / \mathrm{Fe}^{\mathrm{II}}$ redox waves of the $\left[\mathrm{Fe}(\mathrm{L})(\mathrm{Sol})_{3}\right]^{3+}$ species, generated in DCM by treating 12-19 with three equivalents of $\mathrm{AgClO}_{4} \cdot \mathrm{H}_{2} \mathrm{O}$ (DMF) to remove the coordinated chloride ions, are shifted to potentials $(+0.134$ to $+0.156 \mathrm{~V})$ enormously more positive than those observed for the corresponding $\left[\mathrm{Fe}(\mathrm{L}) \mathrm{Cl}_{3}\right]$ complexes, which is expected of the increase in Lewis acidity of the iron(III) center upon solvation. The appearance of the DBSQ/DBC ${ }^{2-}$ couple of the $[\mathrm{Fe}(\mathrm{L})(\mathrm{DBC})(\mathrm{Sol})]^{+}$species at potentials more positive than those of the $[\mathrm{Fe}(\mathrm{L})(\mathrm{DBC})(\mathrm{Cl})]$ species reveals that the semiquinone form of the coordinated $\mathrm{DBC}^{2-}$ in the former is much more stabilized towards oxidation than that in the latter as observed earlier. This interesting observation suggests that the redox behaviour of the $[\mathrm{Fe}(\mathrm{L} 12)(\mathrm{DBC})(\mathrm{Sol})]^{+}$ $[\mathrm{Fe}(\mathrm{L} 16)(\mathrm{DBC})(\mathrm{Sol})]^{+}$adducts are different from those of the $[\mathrm{Fe}(\mathrm{L} 17)(\mathrm{DBC})(\mathrm{Sol})]^{+}-[\mathrm{Fe}(\mathrm{L} 19)(\mathrm{DBC})(\mathrm{Sol})]^{+}$ adducts. It is possible that the adducts $\mathbf{1 2 - 1 6}$ containing the coordinated $\mathrm{NH}$ group is unstable in the presence of added $\mathrm{Et}_{3} \mathrm{~N}$ base. A similar redox behaviour has been observed for the dimeric complex [(TCC)(L20)Fe-O$\mathrm{Fe}(\mathrm{L} 20)(\mathrm{TCC})]$ in acetonitrile, (L20 $=N, N$-dimethyl$N$,-(1-methylimindazol-2-ylmethyl)ethylenediamine). So, it is likely that the adducts $[\mathrm{Fe}(\mathrm{L} 12)(\mathrm{DBC})(\mathrm{Sol})]^{+}$ $[\mathrm{Fe}(\mathrm{L} 16)(\mathrm{DBC})(\mathrm{Sol})]^{+}$undergo dimerisation involving the coordinated NH group in them. Also, the slight differences in the redox potentials of the two waves correspond to two iron(III) centers with slightly different coordination environments in solution. 
Table 5. Kinetic data ${ }^{\mathrm{a}}$ and cleavage products obtained upon reaction of iron(III)-DBC ${ }^{2-}$ adducts with $\mathrm{O}_{2}$ in DMF and DCM solution.

\begin{tabular}{|c|c|c|c|c|c|}
\hline \multirow[t]{2}{*}{ Complex } & \multirow[t]{2}{*}{ Solvent } & \multirow[t]{2}{*}{$k_{\mathrm{O} 2} \times 10^{-2}\left(\mathrm{M}^{-1} \mathrm{~s}^{-1}\right)$} & \multicolumn{3}{|c|}{$\%$ Yield } \\
\hline & & & Intradiol & Extradiol & $\mathrm{E} / \mathrm{I}$ ratio \\
\hline \multirow[t]{2}{*}[\mathrm{Fe}(\mathrm{L}12)(\mathrm{DBC})(\mathrm{Sol})]{$^{+}$} & DMF & 8.70 & 13.8 & 20.4 & 1.4 \\
\hline & DCM & 39.10 & 4.2 & 64.2 & 15.3 \\
\hline \multirow{2}{*}[\mathrm{Fe}(\mathrm{L}13)(\mathrm{DBC})(\mathrm{Sol})]{$^{+}$} & DMF & 9.70 & 28.6 & 33.8 & 1.8 \\
\hline & DCM & 34.50 & 7.0 & 87.7 & 12.5 \\
\hline \multirow[t]{2}{*}[\mathrm{Fe}(\mathrm{L}14)(\mathrm{DBC})(\mathrm{Sol})]{$^{+}$} & DMF & 6.60 & 31.6 & 29.9 & 0.9 \\
\hline & DCM & 46.45 & 7.1 & 52.4 & 7.3 \\
\hline \multirow[t]{2}{*}[\mathrm{Fe}(\mathrm{L}15)(\mathrm{DBC})(\mathrm{Cl})]{} & DMF & 2.80 & 91.3 & $<1$ & - \\
\hline & DCM & - & - & - & - \\
\hline \multirow[t]{2}{*}[\mathrm{Fe}(\mathrm{L}16)(\mathrm{DBC})(\mathrm{Sol})]{$^{+}$} & DMF & 5.20 & 60.5 & 36.0 & 0.6 \\
\hline & DCM & 41.80 & 2.1 & 38.9 & 18.5 \\
\hline \multirow[t]{2}{*}[\mathrm{Fe}(\mathrm{L}17)(\mathrm{DBC})(\mathrm{Sol})]{$^{+}$} & DMF & 0.86 & 37.6 & 30.3 & 0.8 \\
\hline & DCM & 25.04 & 7.6 & 63.0 & 8.2 \\
\hline \multirow[t]{2}{*}[\mathrm{Fe}(\mathrm{L}18)(\mathrm{DBC})(\mathrm{Sol})]{$^{+}$} & DMF & 1.47 & 25.5 & 42.2 & 1.6 \\
\hline & DCM & 47.46 & 7.6 & 72.3 & 9.5 \\
\hline \multirow[t]{2}{*}[\mathrm{Fe}(\mathrm{L}19)(\mathrm{DBC})(\mathrm{Sol})]{$^{+}$} & DMF & 1.74 & 58.2 & 20.5 & 0.4 \\
\hline & DCM & 67.04 & 10.5 & 75.4 & 7.2 \\
\hline
\end{tabular}

${ }^{\mathrm{a}} k_{\mathrm{O} 2}=k_{\text {obs }} /\left[\mathrm{O}_{2}\right]$. The solubility of $\mathrm{O}_{2}$ in DMF is accepted to be $4.86 \mathrm{mM}$; in DCM, $5.80 \mathrm{mM}$ at $25^{\circ} \mathrm{C}$. The kinetic data were obtained by monitoring the disappearance of the lower energy $\mathrm{DBC}^{2-}-$ to-iron(III) LMCT band

The catecholate adducts $[\mathrm{Fe}(\mathrm{L})(\mathrm{DBC})(\mathrm{Cl})]$ of all the complexes afford major amounts of intradiol cleavage products and smaller amounts of extradiol (1.5$12.5 \%)$ products with the extradiol-to-intradiol cleavage product selectivity $(E / I)$ being $\sim 0.5: 1$ in DMF solvent. Interestingly, when the coordinated chloride ions in these adducts are removed to generate the $[\mathrm{Fe}(\mathrm{L})(\mathrm{DBC})(\mathrm{Sol})]^{+}$species in DMF the extradiol cleavage products are isolated in higher yields $(20$ $50 \%$ ) with the product selectivity (E/I) falling in the range 0.3:1-2.0:1. Thus, it is remarkable that all of the solvent coordinated adducts $[\mathrm{Fe}(\mathrm{L})(\mathrm{DBC})(\mathrm{Sol})]^{+}$generated in DCM solution show enhanced yields of extradiol cleavage products (38.9-87.7\%; table 5; scheme 8 ) with the extradiol to intradiol cleavage product selectivity $(\mathrm{E} / \mathrm{I})$ varying in the range 7.2:1 - 18.5:1 (figure 7). A variation of the $N$-alkyl group on the terminal secondary amine nitrogen donor of the present complexes leads to the product selectivity $(E / I)$ varying in the range 7.3:1 - 8.5:1. Upon increasing the steric bulk of the terminal $N$-alkyl substituent, the product selectivity decreases from 15.3: 1 (12) to 12.5 : 1 (13) and then to 7.3: 1 (14). It is possible that the bulky $N$-benzyl group may hinder the approach of $\mathrm{O}_{2}$ to the intermediate iron(II)-semiquinonate radical adduct leading to a decrease in the observed product selectivity. Interestingly, on introducing one more methyl group in $\mathbf{1 2}$ to give 16, the product selectivity increases to $18.5: 1$. It is interesting to note that on replacing one of the pyridyl arms in the bis(pyrid-2ylmethyl)amine by $-\mathrm{CH}_{2} \mathrm{NR}_{2}$ group to obtain 12-16, a tremendous increase in the selectivity $(E: I, 7: 1-18: 1)$ has been observed and is mainly due the high Lewis acidity of iron(III) centre, which may encourage alkenyl migration. Whereas on increasing the bulkiness of the

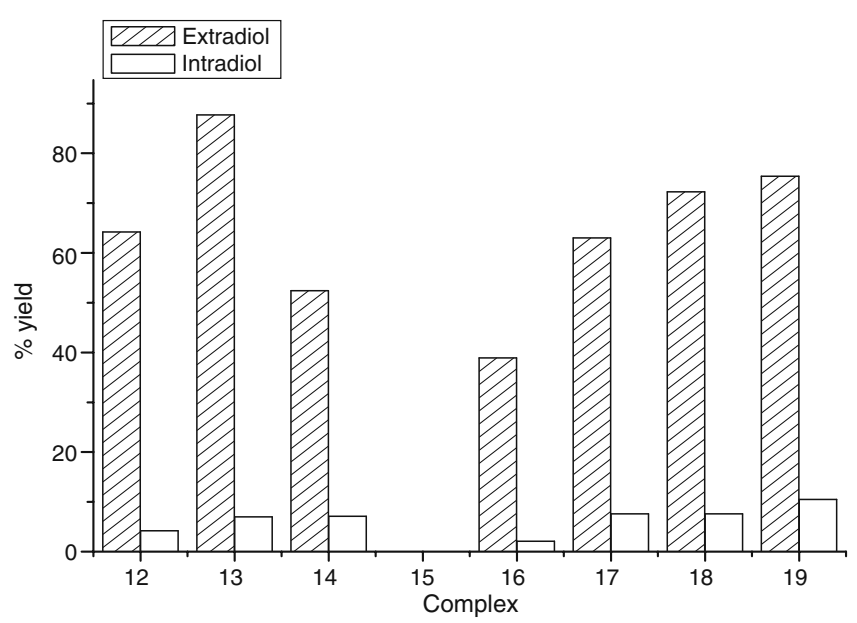

Figure 7. Plot of complexes versus \% yield of oxidative cleavage of catechol in DCM. 


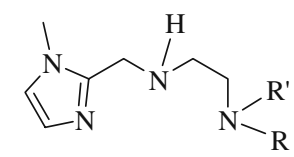

$\mathrm{R}=-\mathrm{CH} 3, \mathrm{R}^{\prime}=-\mathrm{CH} 3 ; \mathrm{L} 20$ $\mathrm{R}=-\mathrm{H}, \mathrm{R}=-(\mathrm{C} 6 \mathrm{H} 5) ; \mathrm{L} 21$

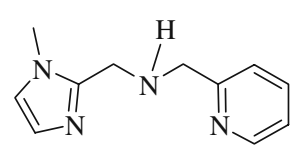

L22

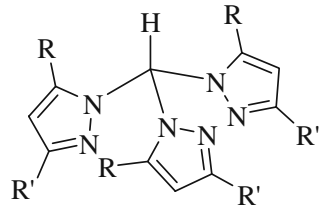

$\mathrm{R}=-\mathrm{H}, \mathrm{R}^{\prime}=-\mathrm{H} ; \quad \mathrm{L} 23$

$\mathrm{R}=-\mathrm{CH}_{3}, \mathrm{R}^{\prime}=-\mathrm{CH}_{3} ; \quad \mathrm{L} 24$

$\mathrm{R}=-\mathrm{H}, \mathrm{R}^{\prime}=-\mathrm{CH}\left(\mathrm{CH}_{3}\right)_{2} ; \mathrm{L} 25$

Scheme 10. Imidazole and pyrazole based tridentate $3 \mathrm{~N}$ ligands.

central and terminal $\mathrm{N}$-atom of the $N, N$-dimethyl$N^{\prime}$-(pyrid-2-ylmethyl)amine ligand, the regiospecificity towards extradiol $(E / I)$ decreases from 18.5 to 7.3 (still it is higher than the bis(pyrid-2-ylmethyl)amine analogues). ${ }^{49}$ This is also observed in iron(III) complexes of triazacyclononane ligands in which all the donors derived from amine $\mathrm{N}$-atom lead to increase the Lewis acidity on the iron(III) center enormously and hence the higher yield of extradiol cleavage products. Also upon introducing methyl groups at amine $\mathrm{N}$-atom of TACN ligand to obtain $\mathrm{Me}_{3} \mathrm{TACN}$, a quantitative amount of extradiol product has been observed with any base. ${ }^{41}$ This illustrates that the increase in Lewis acidity of the iron(III) center enhances the $\mathrm{O}_{2}$ attack and that the steric bulk of the $\mathrm{NMe}_{2}$ group does not discourage it.

The second order reaction rate constants (table 5) of complexes $[\mathrm{Fe}(\mathrm{L})(\mathrm{DBC})(\mathrm{Sol})]^{+}$in DCM solvent is $19>18>17 ; 14>16 \sim 12>13$, which is in accordance with the decrease in Lewis acidity of the adducts in the non-coordinating solvent ( $c f$. above). Interestingly, a plot of the rate of dioxygenation against the $\mathrm{Fe}^{\mathrm{III}} / \mathrm{Fe}^{\text {II }}$ redox potential is linear with 17 showing a negative deviation from it. The higher rate of catechol cleavage of $[\mathrm{Fe}(\mathrm{L} 19)(\mathrm{DBC})(\mathrm{Sol})]^{+}$species is in accordance with the higher steric demand of the central $N$-benzyl group in the complex, which strengthens the iron(III)-catecholate interaction by increasing the Lewis acidity of the iron(III) center and facilitates the electron-transfer from the substrate to $\mathrm{O}_{2}$ in both the intra- and extradiol cleavage mechanisms ${ }^{25,27,65,66,72}$ (cf. above). The plot of $\log \left(k_{\mathrm{O} 2}\right)$ vs. energy of the low-energy catecholateto-metal CT band is also linear with $\mathbf{1 7}$ showing a negative deviation again. Interestingly, the catecholate adducts with $\mathrm{N}$-alkyl substituents at the central nitrogen donor atom including $\mathbf{1 7}$ fall on another straight line $(E / I, 6: 1-7: 1)$ with a higher slope, along with those of bis(pyrid-2-ylmethyl)amine ${ }^{48}$ with branched $N$-alkyl substituents at the central nitrogen donor.

\section{Iron(III) complexes of imidazol- and pyrazol-based linear and tripodal tridentate ligands}

A series of new 1:1 iron(III) complexes of the linear and sterically hindering tripodal tridentate ligands $N, N$-dimethyl- $N^{\prime}$-(1-methyl-1 $H$-imidazol-2-ylmethyl)ethane-1,2-diamine (L20) and $N$-(1-methyl-1Himidazol-2-ylmethyl)- $N^{\prime}$-phenylethane-1,2-diamine (L21), (1-methyl-1 $H$-imidazol-2-ylmethyl)pyrid-2ylmethylamine (L22), tris(1-pyrazolyl)methane (L23), tris(3,5-dimethyl-1-pyrazolyl)methane (L24) and tris(3-iso-propylpyrazolyl)methane (L25) (scheme 10) have been used to explore the necessity of facial coordination of ligands, tune the Lewis acidity of the iron(III) center and hence affect the dioxygenase activity of the complexes.

The two $\mathrm{DBC}^{2-}$-to-iron(III) LMCT band energies increase in the order: $\mathbf{2 2}<\mathbf{2 0}<\mathbf{2 1}$ and a similar variation in band energies are observed for the other catecholate adducts. Also, it is interesting that in DMF the low-energy LMCT band of $\mathbf{2 4}$ is lower in energy than that of $\mathbf{2 3}$ while the low energy band of $\mathbf{2 5}$ is higher in energy than that of 23. It is obvious that incorporation of the sterically demanding iso-propyl substituent in $\mathbf{2 5}$ would hinder the coordination of the pyrazole nitrogen and concomitantly stabilize the $\mathrm{d} \pi^{*}$ orbital leading to a decrease in $\mathrm{d} \pi^{*}$ and catecholate orbital energy gap and hence the shift in the LMCT band to low energy. On the other hand, incorporation of electron-releasing methyl groups on the pyrazole ring in $\mathbf{2 4}$ adduct would enhance the electron density on $\mathrm{d} \pi^{*}$ orbital and destabilize it leading to an increase in $\mathrm{d} \pi^{*}$ and catecholate orbital energy gap and hence the shift in the LMCT band to a higher energy.

The $E_{1 / 2}$ of iron(III) complexes (table 6) of the imidazole ligands follow the trend $\mathbf{2 2}>\mathbf{2 0}>\mathbf{2 1}$ reflecting a decrease in Lewis acidity of iron(III) center along 
Table 6. Electonic spectral, redox potential and kinetic data of iron(III) complexes and their $\mathrm{DBC}^{2-}$ adducts and cleavage products obtained on reaction of iron(III)-DBC ${ }^{2-}$ with $\mathrm{O}_{2}$ in $\mathrm{DMF}$ solution.

\begin{tabular}{|c|c|c|c|c|c|c|}
\hline \multirow[t]{2}{*}{ Complex } & \multirow{2}{*}{$\begin{array}{c}\lambda_{\max } \\
\mathrm{nm}\left(\varepsilon_{\max }, \mathrm{M}^{-1} \mathrm{~cm}^{-1}\right)\end{array}$} & \multirow[t]{2}{*}{$E_{1 / 2}(\mathrm{~V})$} & \multirow[t]{2}{*}{$k_{\mathrm{O} 2}\left(\mathrm{M}^{-1} \mathrm{~s}^{-1}\right)$} & \multicolumn{3}{|c|}{$\%$ yield } \\
\hline & & & & Intradiol & Extradiol & Quinone \\
\hline$\left[\mathrm{Fe}(\mathrm{L} 20) \mathrm{Cl}_{3}\right] \mathbf{2 0}$ & $\begin{array}{l}795(2505) \\
490(1730)\end{array}$ & -0.306 & $0.59 \times 10^{-2}$ & 43.1 & 12.0 & - \\
\hline$\left[\mathrm{Fe}(\mathrm{L} 21) \mathrm{Cl}_{3}\right] \mathbf{2 1}$ & $\begin{array}{l}780(1920) \\
485(1575)\end{array}$ & -0.318 & $0.21 \times 10^{-2}$ & 24.7 & 11.1 & - \\
\hline$\left[\mathrm{Fe}(\mathrm{L} 22) \mathrm{Cl}_{3}\right] 22$ & $\begin{array}{l}718(1600) \\
503(1590)\end{array}$ & -0.372 & $2.40 \times 10^{-2}$ & 40.7 & 6.0 & - \\
\hline$\left[\mathrm{Fe}(\mathrm{L} 23) \mathrm{Cl}_{3}\right] \mathbf{2 3}$ & $\begin{array}{l}660(1710) \\
530(1390)\end{array}$ & -0.432 & $1.85 \times 10^{-2}$ & 5.0 & - & 40.0 \\
\hline$\left[\mathrm{Fe}(\mathrm{L} 24) \mathrm{Cl}_{3}\right] \mathbf{2 4}$ & $\begin{array}{l}655(1670) \\
528(1390)\end{array}$ & -0.444 & $1.90 \times 10^{-2}$ & 1.8 & 13.3 & 22.3 \\
\hline$\left[\mathrm{Fe}(\mathrm{L} 25) \mathrm{Cl}_{3}\right] 25$ & $\begin{array}{l}670(1920) \\
546(1620)\end{array}$ & -0.398 & $2.39 \times 10^{-2}$ & 2.9 & 6.0 & 16.3 \\
\hline
\end{tabular}

${ }^{\mathrm{a}} k_{\mathrm{O} 2}=k_{\text {obs }} /\left[\mathrm{O}_{2}\right]$. The solubility of $\mathrm{O}_{2}$ in DMF is accepted to be $4.86 \mathrm{mM}$. The kinetic data were obtained by monitoring the disappearance of the lower energy $\mathrm{DBC}^{2-}$-to-iron(III) LMCT band

this series. With the replacement of the pyridyl moiety in $\mathbf{2 2}$ by he electron-releasing groups as in $\mathbf{2 0}$ and 21, the Lewis acidity of iron(III) centre decreases. The $\mathrm{Fe}^{\mathrm{III}} / \mathrm{Fe}^{\mathrm{II}}$ redox potentials of the pyrazole-based complexes 23-25 $(-0.398$ to $-0.444 \mathrm{~V})$ are more negative than those for the pyridyl-based complexes 20-22 clearly suggesting that the tripodal ligands are more strongly coordinated than the linear ligands. The $\mathrm{Fe}^{\mathrm{III}} / \mathrm{Fe}^{\mathrm{II}}$ redox potentials of the tripodal ligand complexes follow the trend $\mathbf{2 5}>\mathbf{2 3}>\mathbf{2 4}$, which represents a decrease in Lewis acidity of the iron(III) center along this series. On introducing the iso-propyl group on the 3-position of pyrazole rings in $\mathbf{2 3}$ to give $\mathbf{2 5}$, the sterically hindering iso-propyl group weakens the coordination of N2 nitrogen of pyrazolyl ring leading to confer an enhanced Lewis acidity of the iron(III) center. It is possible that upon $\mathrm{DBC}^{2-}$ coordination one of the tripodal arms in 23-25 dissociate leading to an increase in Lewis acidity of the iron(III) center and hence the same extent of stabilization of the semiquinone radical towards oxidation for both the imidazole- and pyrazole-based complexes.

The complexes 20-22 with imidazole nitrogen donors afford major amounts of the intradiol cleavage products and smaller amounts of the extradiol cleavage products in DMF solvent with the extradiol to intradiol product selectivity (E:I) varying from 0.14: 1 to 0.45 : 1 . Interestingly, when the coordinated chloride ion in $[\mathrm{Fe}(\mathrm{L})(\mathrm{DBC}) \mathrm{Cl}]$ is removed to generate $[\mathrm{Fe}(\mathrm{L})(\mathrm{DBC})(\mathrm{Sol})]^{+}$species in DMF solvent, the product selectivity (E:I) increases to 0.6 : 1-1.8:1 (table 6), with the adduct $[\mathrm{Fe}(\mathbf{L 2 0})(\mathrm{DBC})(\mathrm{Sol})]^{+}$giving $38 \%$ yield of extradiol products. In contrast to the iron(III) complexes 20-22 of imidazole-based ligands, those of the tripodal pyrazole-based ligands (2325) effect the oxidation of $\mathrm{H} 2 \mathrm{DBC}$ on exposure to $\mathrm{O}_{2}$ to afford mainly the benzoquinone product; also, small amounts of extradiol cleavage products and very small amounts of intradiol cleavage products are also obtained. Also, the observation of a higher E:I value for $[\mathrm{Fe}(\mathbf{L 2 0})(\mathrm{DBC}) \mathrm{Cl}]$ reveals that the sterically hindering terminal $-\mathrm{NMe}_{2}$ group of the ligand appears to be oriented away from the $\mathrm{sp}^{3}$ hybridized carbon atom of the catecholate substrate in the tridentate peroxo intermediate and facilitates alkenyl migration to give enhanced regioselective extradiol cleavage products. ${ }^{49}$ Also, upon replacement of one of the pyridyl moieties in the 1:1 iron(III) complex ${ }^{49}$ of $N^{\prime}$-(pyrid2-ylmethyl)- $N, N$-dimethylethylenediamine by $N$-Meimidazolyl moiety to get $[\mathrm{Fe}(\mathbf{L 2 0})(\mathrm{DBC}) \mathrm{Cl}]$ a dramatic decrease in product selectivity (E: I) from 18.5: 1.0 to 1.83: 1.0 is observed. Obviously, the sterically less hindering $N$-methylimidazolyl moiety favours the attack of molecular oxygen and also facilitates acyl rather than alkenyl migration to give intradiol cleavage products. As illustrated above for 20-22, the $\mathrm{DBC}^{2-}$ adducts 


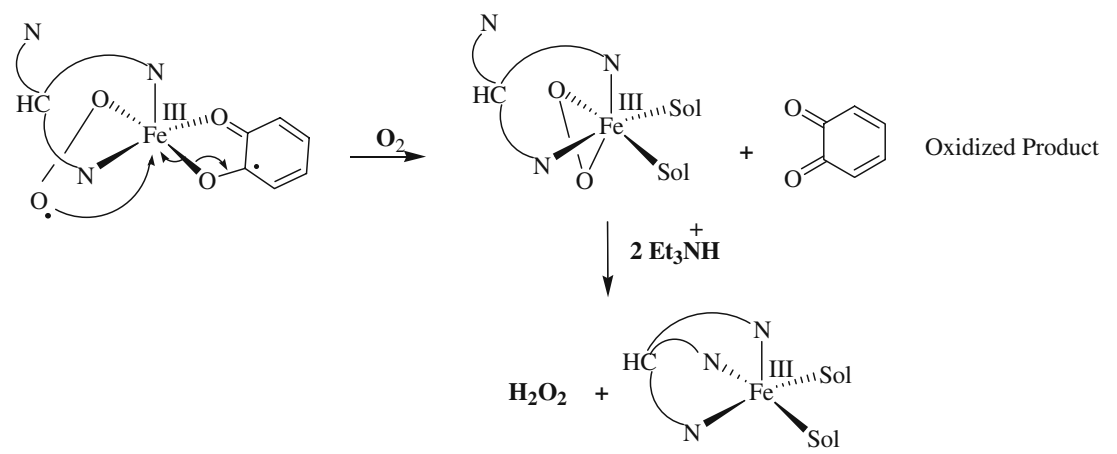

Scheme 11. Proposed mechanism for the formation of quinone.

of 23-25 are also expected to yield extradiol cleavage products upon oxygenation since they contain the tripodal ligands facially coordinated and also a coordination position vacant for dioxygen binding. However, interestingly, all of them yield mainly the oxidized product benzoquinone. It is clear that they are not prone to form the intermediate $\left[(\mathrm{L})(\mathrm{DBSQ}) \mathrm{Fe}(\mathrm{III}) \mathrm{O}_{2}\right]^{-}$ responsible for catechol cleavage. Thus, the formation of the oxidized products for $\mathbf{2 3}-\mathbf{2 5}$ can be explained by assuming equatorial attack of dioxygen on the $\mathrm{DBC}^{2-}$ adducts of the complexes (scheme 11) in which one of the arms of the tripodal ligand (trans to one of the strong $\mathrm{Fe}-\mathrm{O}_{\text {cat }}$ bonds) is displaced from the octahedral coordination sphere due to the sterically constrained 6,6,6chelate ring system. The equatorially bound dioxygen is unable to attack the semiquinone radical located in the same plane and hence the oxidation product benzoquinone is formed in larger amounts as for the BPY and TERPY complexes. The extradiol cleavage products are obtained when dioxygen attacks the axial position of the adduct with or without dissociation of one of the arms of the tripodal ligand, while the intradiol cleavage products are formed by the concerted ${ }^{72}$ dioxygen attack on iron(III) and the carbon atom of the bound catecholate. The yield of quinone product for the $[\mathrm{Fe}(\mathrm{L})(\mathrm{DBC}) \mathrm{Cl}]$ adducts of 23-25 with pyrazolyl ligands in DMF decreases along the series $23>\mathbf{2 4}>\mathbf{2 5}$ (table 6) while their second order reaction rate constants vary in the order $25>\mathbf{2 4} \sim \mathbf{2 3}$. As substrate binding is the first step in the mechanism, the highest Lewis acidity of $\mathbf{2 5}$ ( $c f$. above) would encourage its strongest binding with both anionic $\mathrm{DBC}^{2-}$ and dioxygen leading to the highest yield of the benzoquinone product.

Similarly, the catecholate adduct of $\mathbf{2 5}$ with a sterically hindering iso-propyl substituent ( $c f$. above) would be expected to show a decreased rate of quinone formation but it exhibits the highest rate of reaction. Therefore, it appears that the bulky iso-propyl groups on the pyrazolyl ring in $\mathbf{2 5}$ do not hinder the approach of $\mathrm{DBC}^{2-}$ and dioxygen and it is the highest Lewis acidity of $\mathbf{2 5}$ which strengthens the iron(III)-catecholate interaction in the alkylperoxo intermediate $\left[(\mathbf{L 6})(\mathrm{DBSQ}) \mathrm{Fe}(\mathrm{III}) \mathrm{O}_{2}\right]^{-}$leading to facile dioxygen attack and hence the highest rate of dioxygenation is observed. ${ }^{48,49}$ Also, the dissociation of one of the sterically hindering pyrazolyl arms from the coordination sphere ( $c f$. above) would lead to an increase in Lewis acidity of the iron(III) center. Thus it is remarkable that the iron(III) complexes with facially coordinated tris(pyrazolyl)methane ligand yields only the quinone product obviously due to bidentate coordination of the tripodal ligand. Also, for complexes of both the imidazole- and pyrazole-based $3 \mathrm{~N}$ ligands the steric constraint around iron(III) determines the yield of dioxygenation products while the Lewis acidity of the iron(III) center determines the observed rates of dioxygenation.

\section{Conclusions}

A few mononuclear iron(III) complexes of meridionally coordinating tridentate ligands have been prepared and studied as spectral and functional models for the intradiol-cleaving catechol 1,2-dioxygenase enzymes. Interestingly, meridional carboxylate coordination is found to be suitable to elicit intradiol rather than extradiol cleavage, however, with a decrease in reaction rate.

Also, a series of iron(III) complexes of the type $\left[\mathrm{Fe}(\mathrm{L}) \mathrm{Cl}_{3}\right]$, where $\mathrm{L}$ is the linear $N$-alkyl substituted bis(pyrid-2-ylmethyl)amine, $N$-alkyl substituted $N$ (pyrid-2-ylmethyl)ethylenediamine, linear tridentate $3 \mathrm{~N}$ ligands containing imidazolyl moieties and linear tripodal ligands containing pyrazolyl moieties have been isolated and studied as structural and functional models for catechol dioxygenase enzymes. The X-ray 
crystal structures of many of the complexes reveal that the $3 \mathrm{~N}$ ligands are facially coordinated. The effect of $\mathrm{N}$-methyl substitution at the central and terminal amine nitrogen atoms in these structures have been illustrated. Also, the structure of the tetrachlorocatecholate adduct of one of these complexes has been determined as a model for enzyme-substrate adduct. The similarity between the electronic spectra of the catecholate adducts of the complexes and the catecholatebound enzymes suggests that the catecholato dianion is chelated to iron(III) centre in the latter. The observation of two new $\mathrm{cat}^{2-} / \mathrm{dbc}^{2-}$-to-Fe(III) LMCT bands on adding simple and substituted catechols to the chloride complexes illustrates the deprotonation of catechols on binding to iron(III) even in the absence of added base. The primary ligand functionalities play a very important role in modulating the Lewis acidity of the iron(III) centre, as revealed by their $\mathrm{Fe}(\mathrm{III}) / \mathrm{Fe}(\mathrm{II})$ redox potentials.

Our studies reveal that stereo-electronic factors like the Lewis acidity of the iron(III) centre and the steric demand of ligands, as regulated by the $N$-alkyl subtituents, determine the cleavage yields and the rate of dioxygenation in DCM and DMF solvents. It is remarkable that the iron(III)-catecholate adducts with the $N$-alkyl groups $n$-propyl, iso-butyl, iso-propyl, and cyclohexyl confer enhanced selectivity toward extradiol cleavage, whereas that with a $N$-tert-butyl substituent enhances the reaction rate. The extradiol-tointradiol product selectivity is enhanced by replacing one of the coordinated pyridylmethyl arms in the catecholate adduct of iron(III) complex of bis(pyrid2-ylmethyl)amine by the sterically demanding and weakly coordinating $-\mathrm{CH}_{2} \mathrm{NHR}$ arm and upon incorporation of one more $N$-methyl group at the terminal nitrogen atom of the $3 \mathrm{~N}$ ligands. However, it decreases upon introducing $N$-alkyl substituents at the central nitrogen atom of the ligands. In sharp contrast to all these complexes, the pyrazole-containing tripodal ligand complexes yield mainly the oxidized product benzoquinone. All the observations provide a valuable support to the substrate-activation and oxygen activation mechanisms proposed for intradiol cleavage of catechol.

\section{References}

1. Phale P S, Basu A, Majhi Deveryshetty J, VamsheKrishna C and Shrivastava R 2007 J. Integ. Biol. 11 252

2. (a) Que L Jr and Ho R Y N 1996 Chem. Rev. 96 2607; (b) Dagley S 1975 Essays Biochem. 1181
3. Solomon E I, Brunold T C, Davis M I, Kemsley J N, Lee S-K, Lehnert N, Neese F, Skulan A J, Yang Y-S and Zhou J 2000 Chem. Rev. 100235

4. Bugg T D H and Lin G 2001 Chem. Commun. 11941

5. Hayaishi O, Katagiri M and Rothberg S 1955 J. Am. Chem. Soc. 775450

6. Kojima Y, Itada N and Hayaishi O 1961 J. Biol. Chem. 2362223

7. Hayaishi O 1966 Bacteriol. Rev. 30720

8. Ohlendorf D H, Lipscomb J D and Weber P C 1988 Nature 336403

9. Ohlendorf D H, Orville A M and Lipscomb J D 1994 J. Mol. Biol. 244586

10. Vetting M W and Ohlendorf D H 2000 Structure 8429

11. Orville A M, Lipscomb J D and Ohlendorf D H 1997 Biochemistry 3610052

12. Vetting M W, Earhart C A and Ohlendorf D H 1994 J. Mol. Biol. 236372

13. Elgren T E, Orville A M, Kelly K A, Lipscomb J D, Ohlendorf D H and Que L Jr 1997 Biochemistry 36 11504

14. Han S, Eltis L D, Timmis K N, Muchmore S W and Bolin J T 1995 Science 270976

15. Sugimoto K, Senda T, Aoshima H, Masai E, Fukuda M and Mitsui Y 1999 Structure 7953

16. Kita A, Kita S I, Fujisawa I, Inaka K, Ishida T, Horiike K, Nozaki M and Miki K 1998 Structure 725

17. Vaillancourt F H, Barbosa C J, Spiro T G, Bolin J T, Blades M W, Turner R F B and Eltis L D 2002 J. Am. Chem. Soc. 1242485

18. Uragami Y, Senda T, Sugimoto K, Sato N, Nagarajan V, Masai E, Fukuda M and Mitsui Y 2001 J. Inorg. Biochem. 83269

19. Sato N, Uragami Y, Nishizaki T, Takahashi Y, Sazaki G, Sugimoto K, Nonaka T, Masai E, Fukuda M and Senda T 2002 J. Mol. Biol. 321621

20. Lin G, Reid G and Bugg T D H 2000 Chem. Commun. 1119

21. Costas M, Mehn M P, Jensen M P and Que L Jr 2004 Chem. Rev. 104939

22. Kovaleva E G and Lipscomb J D 2007 Science 316453

23. Viswanathan R, Palaniandavar M, Balasubramanian T and Muthiah P T 1996 J. Chem. Soc. Dalton. Trans. 2519

24. Viswanathan R, Palaniandavar M, Balasubramanian T and Muthiah P T 1998 Inorg. Chem. 372943

25. Velusamy M, Palaniandavar M, Srinivasagopalan R and Kulkarni G U 2003 Inorg. Chem. 428283

26. Velusamy M, Mayilmurugan $\mathrm{R}$ and Palaniandavar $\mathrm{M}$ 2004 Inorg. Chem. 436284

27. Velusamy M, Mayilmurugan $\mathrm{R}$ and Palaniandavar $\mathrm{M}$ 2005 J. Inorg. Biochem. 991032

28. Pascaly M, Duda M, Schweppe F, Zurlinden K, Muller F K and Krebs B 2001 J. Chem. Soc. Dalton Trans. 828

29. Ogo S, Yamahara R, Funabiki T, Masuda H and Watanabe Y 2001 Chem. Lett. 301062

30. Cox D D and Que L Jr 1988 J. Am. Chem. Soc. 1108085

31. Jang H G, Cox D D and Que L Jr 1991 J. Am. Chem. Soc. 1139200

32. Koch W O, Schünemann V, Gerdan M, Trautwein A X and Krüger H J 1998 Chem. Eur. J. 41255 
33. Raffard N, Carina R, Simaan A J, Sainton J, Riviere E, Tchertanov L, Bourcier S, Bouchoux G, Delroisse M, Banse F and Girerd J J 2001 Eur. J. Inorg. Chem. 2249

34. Shu L, Chiou Y M, Orville A M, Miller M A, Lipscomb J D and Que L Jr 1995 Biochemistry 346649

35. Davis M I, Wasinger E C, Decker A, Pau M Y M, Vaillancourt F H, Bolin J T, Eltis L D, Hedman B, Hodgson K O and Solomon E I 2003 J. Am. Chem. Soc. 12511214

36. Costas M, Mehn M P, Jensen M P and Que L Jr 2004 Chem. Rev. 104939

37. Funabiki T, Mizoguchi A, Sugimoto T, Tada S, Tsugi M, Sakamoto H and Yoshida S 1986 J. Am. Chem. Soc. 108 2921

38. Dei A, Gatteschi D and Pardi L 1993 Inorg. Chem. 32 1389

39. Lin G, Reid G and Bugg T D H 2001 J. Am. Chem. Soc. 1235030

40. Ito M and Que L Jr 1997 Angew. Chem., Int. Ed. Engl. 361342

41. Jo D-H and Que L Jr 2000 Angew. Chem., Int. Ed. 39 4284

42. Lim J H, Park T H, Lee H-J, Lee K-B and Jang H G 1999 Bull. Korean Chem. Soc. 201428

43. Chiou Y-M and Que L Jr 1995 Inorg. Chem. 343577

44. Mayilmurugan R, Suresh E and Palaniandavar M 2007 Inorg. Chem. 466038

45. Dhanalakshmi T, Bhuvaneshwari $\mathrm{M}$ and Palaniandavar M 2006 J. Inorg. Biochem. 1001527

46. Bruijnincx P C A, Lutz M, Spek A L, Hagen W R, Weckhuysen B M, Koten G and Klein Gebbink R J M 2007 J. Am. Chem. Soc. 1292275

47. Wagner M, Limberg C and Tietz T 2009 Chem. Eur. J. 155567

48. Visvaganesan K, Mayilmurugan R, Suresh E and Palaniandavar M 2007 Inorg. Chem. 4610294

49. Sundaravel K, Dhanalakshmi T, Suresh E and Palaniandavar M 2008 Dalton Trans. 7012

50. Dhanalkshmi T, Suresh E and Palaniandavar M 2009 Dalton Trans. 8317

51. Laine P, Gourdon A and Launay J-P 1995 Inorg. Chem. 345156

52. Wang X, Wang S, Li L, Sundberg E B and Gacho G P 2003 Inorg. Chem. 42799
53. Viswanathan R, Palaniandavar M, Balasubramanian T and Muthiah P T 1996 J. Chem. Soc. Dalton. Trans. 2519

54. Viswanathan R, Palaniandavar M, Balasubramanian T and Muthiah P T 1998 Inorg. Chem. 372943

55. Pascaly M, Duda M, Schweppe F, Zurlinden K, Muller F K and Krebs B 2001 J. Chem. Soc. Dalton Trans. 828

56. Mialane $P$, Anxolabéhère-Mallart E, Blondin G, Nivorojkine A, Guilhem J, Tchertanova L, Cesario M, Ravi N, Bominaar E, Girerd J-J and Münck E 1997 Inorg. Chim. Acta 263367

57. Yamahara R, Ogo S, Watanabe Y, Funabiki T, Jitsukawa $\mathrm{K}$, Masuda $\mathrm{H}$ and Einaga $\mathrm{H}$ Inorg. Chim. Acta 300-302 587

58. Thomas K R J, Velusamy M and Palaniandavar P 1998 Acta Crystallogr. C54 741

59. Rodriguez M C, Lambert F, Morgenstern-Badarau I, Cesario M, Guilhem J, Keita B and Nadjo L 1997 Inorg. Chem. 363525

60. Mandon D, Nopper A, Litrol T and Goetz S 2001 Inorg. Chem. 404803

61. White L S, Nilsson P V, Pignolet L H and Que L Jr 1984 J. Am. Chem. Soc. 1068312

62. Viswanathan R and Palaniandavar M 1995 J. Chem. Soc. Dalton Trans. 1259

63. Cox D D and Que L Jr 1988 J. Am. Chem. Soc. 1108085

64. Ogihara T, Hikichi S, Akita M and Moro-oka Y 1998 Inorg. Chem. 372614

65. Merkel M, Muller F K and Krebs B 2002 Inorg. Chim. Acta. 337308

66. Lipscomb J D and Orville A M 1992 Met. Ions. Biol. Syst. 28243

67. Hitomi Y, Yoshida M, Higuchi M, Minami H, Tanaka T and Funabiki T 2005 J. Inorg. Biochem. 99755

68. Barbaro P, Bianchini C, Mealli C and Meli A 1991 J. Am. Chem. Soc. 1133181

69. For a comprehensive review of the Baeyer-Villiger oxidation see: Krow G R 1993 Org. React. 43251

70. Cullis P M, Arnold J R P, Clarke M, Howell R, De Mira M, Naylor M and Nicholls D 1987 J. Chem. Soc., Chem. Commun. 1088

71. Goodman R M and Kishi Y 1994 J. Org. Chem. 59 5125; 1998 J. Am. Chem. Soc. 1209392

72. Pau M Y M, Davis M I, Orville A M, Lipscomb J D and Solomon E I 2007 J. Am. Chem. Soc. 1291944 